\title{
Techno-economic analysis of a new downstream process for the production of astaxanthin from the microalgae Haematococcus pluvialis
}

\author{
Andreas Bauer ${ }^{*}$ and Mirjana Minceva
}

\begin{abstract}
The biotechnological production of the carotenoid astaxanthin is done with the microalgae Haematococcus pluvialis (H. pluvialis). Under nutrient deficiency and light stress, H. pluvialis accumulates astaxanthin intracellularly and forms a resistant cyst cell wall that impedes direct astaxanthin extraction. Therefore, a complex downstream process is required, including centrifugation, mechanical cell wall disruption, drying, and supercritical extraction of astaxanthin with $\mathrm{CO}_{2}$. In this work, an alternative downstream process based on the direct extraction of astaxanthin from the algal broth into ethyl acetate using a centrifugal partition extractor (CPE) was developed. A mechanical cell wall disruption or germination of the cysts was carried out to make astaxanthin accessible to the solvent. Zoospores containing astaxanthin are released when growth conditions are applied to cyst cells, from which astaxanthin can directly be extracted into ethyl acetate. Energy-intensive unit operations such as spray-drying and extraction with supercritical $\mathrm{CO}_{2}$ can be replaced by directly extracting astaxanthin into ethyl acetate. Extraction yields of $85 \%$ were reached, and $3.5 \mathrm{~g}$ of oleoresin could be extracted from $7.85 \mathrm{~g}$ homogenised H. pluvialis biomass using a CPE unit with $244 \mathrm{~mL}$ column volume. A techno-economic analysis was done for a hypothetical $H$. pluvialis production facility with an annual biomass output of $8910 \mathrm{~kg}$. Four downstream scenarios were examined, comparing the novel process of astaxanthin extraction from homogenised cyst cells and germinated zoospores via CPE extraction with the conventional industrial process using in-house or supercritical $\mathrm{CO}_{2}$ extraction via an external service provider. After 10 years of operation, the highest net present value (NPV) was determined for the CPE extraction from germinated zoospores.
\end{abstract}

Keywords: Haematococcus pluvialis, Astaxanthin, Techno-economic analysis, Liquid-liquid chromatography, Centrifugal partition extraction, Downstream processing

\section{Introduction}

The red carotenoid "astaxanthin" is used as a feed additive for colouring salmon, seafood, and poultry (Shah et al. 2016). It is increasingly used in the cosmetics and dietary supplement industry due to its oxidative characteristics and healthful properties ( $\mathrm{Li}$ et al. 2020;

\footnotetext{
*Correspondence: msc.andreas.bauer@tum.de

Biothermodynamics, TUM School of Life Sciences, Technical University of Munich, Maximus-von-Imhof-Forum 2, 85354 Freising, Germany
}

Astaxanthin Market Size, Share \& Trends Analysis Report 2020). Astaxanthin can be chemically synthesised or biotechnologically produced with the microalgae $H$. pluvialis (Nguyen 2013). Due to the increased consumer demand for sustainable ecological products, the market for biotechnologically produced astaxanthin is expected to rise to $\$ 148.1$ million US (Haematococcus Pluvialis Market 2021).

The life cycle of $H$. pluvialis can be divided into mobile and non-mobile phases (Zhang et al. 2017). During 
favourable growth conditions, the microalgae live mainly as green, flagellated vegetative cells (Fig. 1a). Vegetative cells consist of a cell membrane and an extracellular gelatinous matrix (Hagen et al. 2002). Under stress conditions (nitrate depletion and high light intensity), the vegetative cells become round, expand in cell size, and form immobile aplanospores (Fig. 1b). They accumulate astaxanthin in the cytoplasm of the cell under persistent stress conditions (Fig. 1C) and develop a rigid and resistant cell wall (Fig. 1d) (Hagen et al. 2002; Grünewald et al. 1997). When growth conditions are applied to cyst cells, these form a sporangium and release astaxanthin containing zoospores (Fig. 1e), which only have a thin cell matrix
(Fig. 1f). After a specific time, the zoospores become round and form non-motile aplanospores (Fig. 1g). The industrial process is usually performed phototrophically in two steps. In the first stage of the process, the algal biomass is cultivated to reach high cell concentrations under optimal growth conditions, with a sufficient supply of nutrients such as nitrates and phosphates (Nahidian et al. 2018), $\mathrm{CO}_{2}$ (Chekanov et al. 2017), and artificial lighting (Katsuda et al. 2004; Xi et al. 2016b). Under nitrate and phosphate deficiency and light stress (Xi et al. 2016a; Sun et al. 2015), the astaxanthin synthesis is initiated in the second step. Astaxanthin accumulation is accompanied by the formation of a resistant cyst

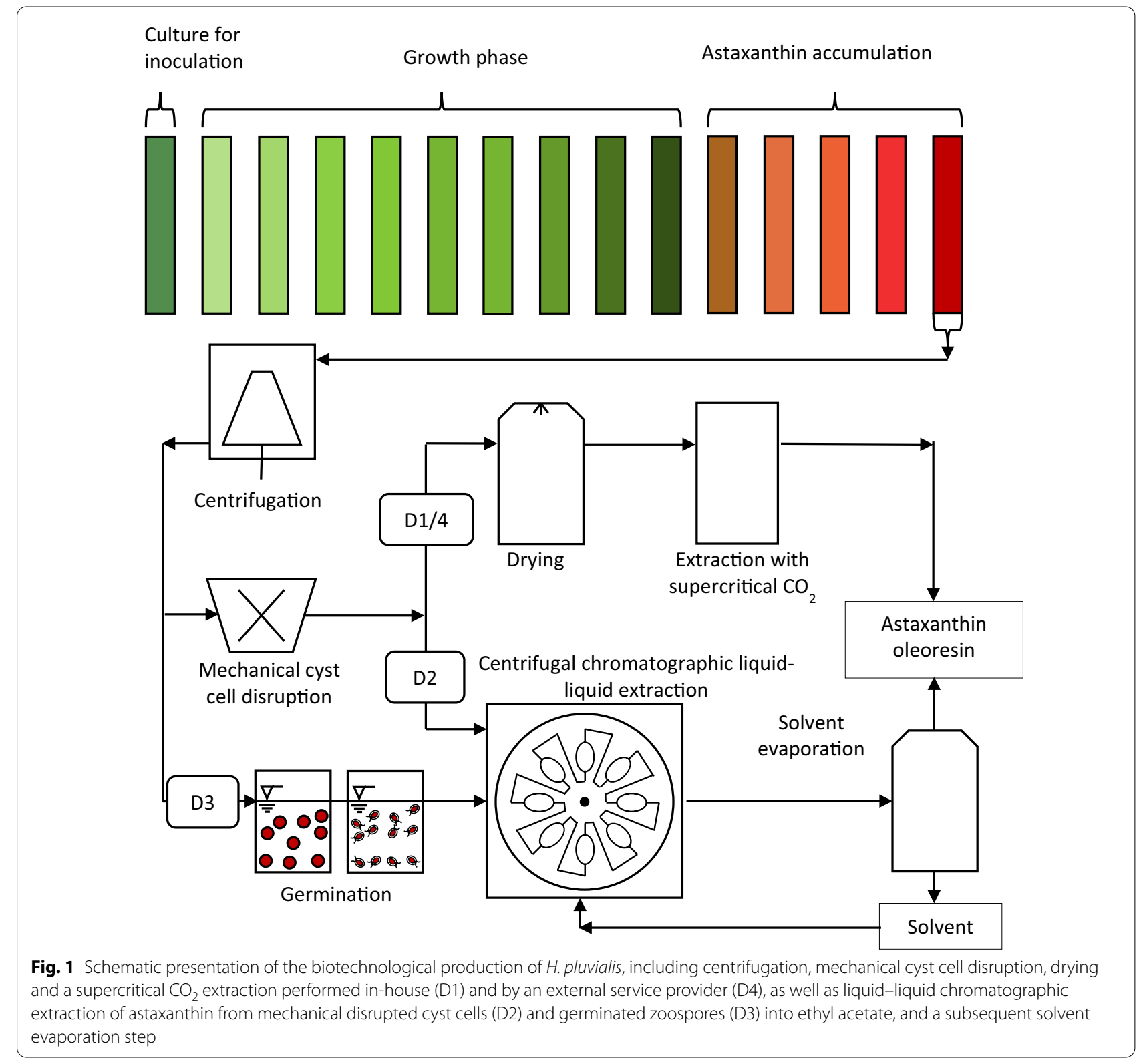


cell wall, which impedes direct and efficient astaxanthin extraction. Consequently, a complex downstream process is required, including harvesting the biomass via centrifugation, mechanical cell wall disruption, spray-drying, and the extraction of astaxanthin using supercritical $\mathrm{CO}_{2}$ (Panis and Carreon 2016). The current industrial process is shown schematically in Fig. 2, including the conventional downstream process with in-house (D1) supercritical $\mathrm{CO}_{2}$ extraction and via an external service provider (D4). Downstream processing in biotechnological processes often represents a bottleneck, showing potential for considerable economic savings (Hatti-Kaul 2000; Minceva and Bauer 2020). Microalgae harvesting may already account for up to $20-30 \%$ of the total production costs (Panis and Carreon 2016).

Due to the highly rigid cell wall of the $H$. pluvialis cyst cells, the mechanical cell wall disruption also represents a procedural challenge. Energy-intensive mechanical processes such as bead milling or high-pressure homogenisation are used for industrial cell wall disruption. Up to three-cycle repetitions are needed to achieve sufficient cell wall disruption efficiency using high-pressure homogenisation (Praveenkumar et al. 2020). Drying represents an energy-intensive process step due to the high evaporation enthalpy of water $\left(\Delta h_{\text {vap. }}=2442 \mathrm{~kJ} \mathrm{~kg}^{-1}\right.$ at $25{ }^{\circ} \mathrm{C}$ ) (Lide 2005). Spray-drying is commonly used in

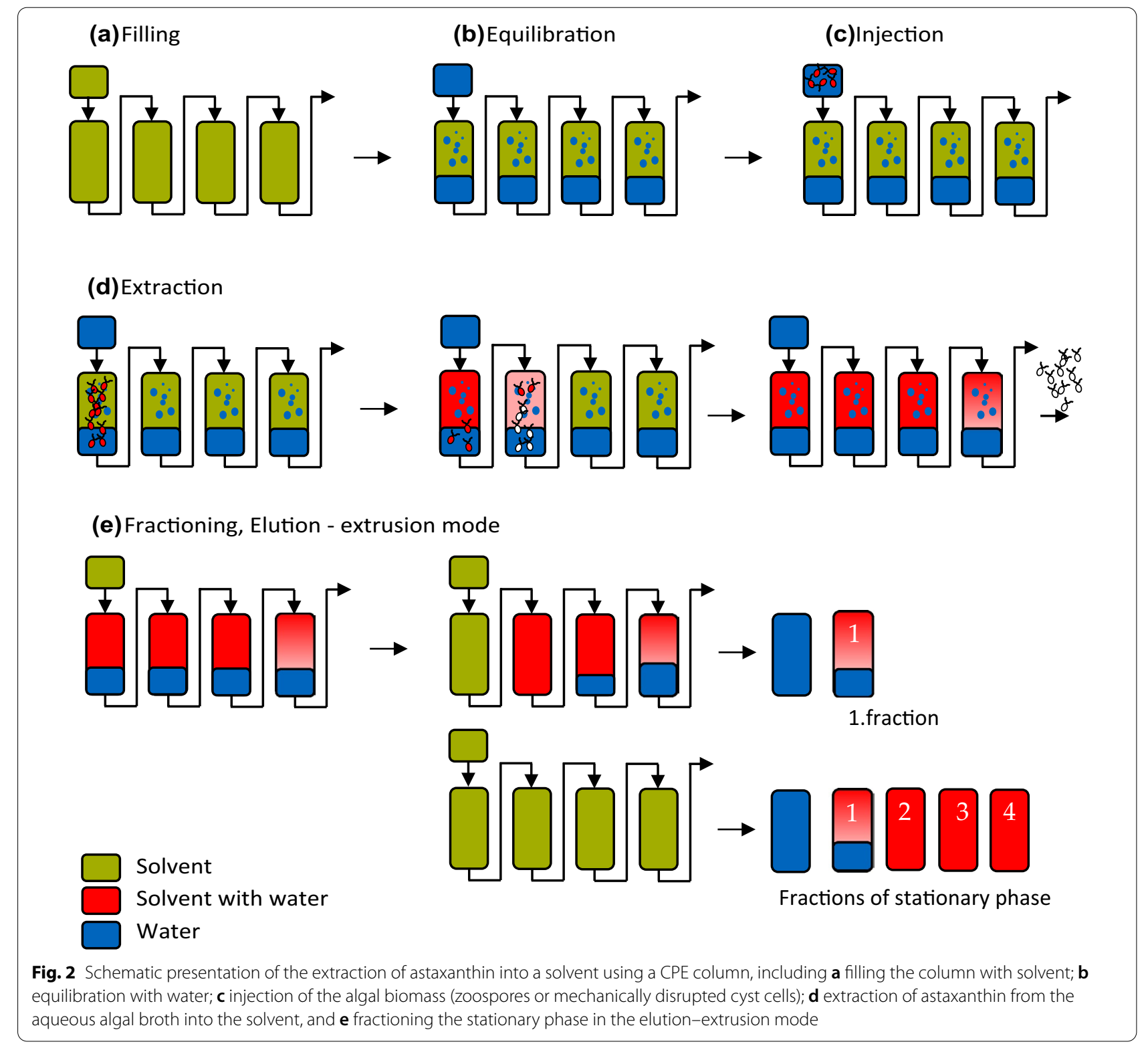


industry for drying $H$. pluvialis biomass. In this process step, the risk of astaxanthin degradation due to high temperatures or oxidation needs to be considered. The biomass obtained in the drying step needs to show defined densities for it to be processed in the subsequent supercritical $\mathrm{CO}_{2}$ extraction. In literature, supercritical $\mathrm{CO}_{2}$ extraction of astaxanthin from $\mathrm{H}$. pluvialis was intensively studied (Krichnavaruk et al. 2008; Molino et al. 2018). Similar maximum extraction yields of $94 \%$ and $92 \%$ were reported for supercritical $\mathrm{CO}_{2}$ extraction at a pressure of $550 \mathrm{bar}$ and $50{ }^{\circ} \mathrm{C}$ (without co-solvent) and $65{ }^{\circ} \mathrm{C}$ (with ethanol as co-solvent), respectively (Molino et al. 2018). An increase in the temperature to $80^{\circ} \mathrm{C}$ was accompanied by a strong decrease in the yield, which was attributed to the degradation of astaxanthin at these temperatures (Molino et al. 2018). In another study, significantly lower yields of approx. 25\% were obtained at a pressure of $400 \mathrm{bar}$ and $70{ }^{\circ} \mathrm{C}$. The yield could be increased to $36 \%$ by adding $10 \mathrm{v} / \mathrm{v}$ soybean oil as co-solvent (Krichnavaruk et al. 2008). On an industrial scale, up to 1000 bar are used for supercritical $\mathrm{CO}_{2}$ extraction of astaxanthin from $\mathrm{H}$. pluvialis. Applying pressures $\geq 800$ bar and a temperature range from 60 to $80{ }^{\circ} \mathrm{C}$, extraction yields larger than $90 \%$ have been reported on an industrial scale (Tippelt 2019).

So far, the biotechnological production of astaxanthin from $H$. pluvialis cannot compete with synthetically produced astaxanthin in terms of production costs $(\mathrm{Li}$ et al. 2011). Several studies are presented in the literature to improve the downstream process of biotechnological astaxanthin production (Khoo et al. 2019b). These include alternatives to mechanical cyst disruption using hydrochloric acid or sodium hydroxide, followed by extraction using acetone, where extraction yields of $35 \%$ and 30\% were reached (Mendes-Pinto et al. 2001). Other alternatives are magnetic-assisted extraction (Zhao et al. 2016) and ultrasound-assisted solvent extraction from dried biomass (Zou et al. 2013). Also, ionic liquids were used to extract astaxanthin from germinated zoospores (Praveenkumar et al. 2015) or dried cyst cell biomass (Liu et al. 2019). Using the $\mathrm{CO}_{2}$-based ionic liquid dimethylammonium dimethylcarbamate, extraction yields of $93 \%$ were reached for the extraction from dried cyst biomass (Khoo et al. 2021). Using a liquid biphasic floating system composed of 2-propanol and $\left(\mathrm{NH}_{4}\right)_{2} \mathrm{SO}_{4}$, from $10 \mathrm{mg}$ dried and disrupted $H$. pluvialis biomass dissolved in the salt-rich phase, extraction yields of $95 \%$ could be achieved within 15 min (Khoo et al. 2019a). Integrating an ultrasound horn, this process could be further optimised and scaled up to extract $500 \mathrm{mg}$ dried $H$. pluvialis biomass, where yields of $84 \%$ could be reached (Khoo et al. 2020). In this study, two novel downstream processes (D2 and D3) were developed to extract astaxanthin from mechanically disrupted cyst cells (D2) or germinated zoospores (D3) directly from the fermentation broth into ethyl acetate using a liquid-liquid chromatographic column. In both cases, the astaxanthin oleoresin could be recovered after evaporation of ethyl acetate. The energyintensive drying step and extraction with supercritical $\mathrm{CO}_{2}$ can be replaced in the novel downstream processes. The new downstream processes were compared with D1 and D4, which present the current industrial downstream process, including mechanical cell wall disruption, homogenisation, drying and extraction with supercritical $\mathrm{CO}_{2}$. In scenario D1, the supercritical $\mathrm{CO}_{2}$ extraction is performed in-house, in $\mathrm{D} 4$ it was considered to be carried out by an external service provider.

The core of the new downstream processes D2 and D3 is the liquid-liquid extraction of astaxanthin from the algal broth into ethyl acetate using a liquid-liquid chromatographic unit. Liquid-liquid chromatography is a solid support-free chromatographic method based on the distribution of solutes between two liquid phases. One of the two liquid phases (ethyl acetate saturated with water in processes D2 and D3) is held stationary in the unit by a centrifugal force. The other phase, the mobile phase (homogenised cyst cells in D2 and germinated zoospores in D3), is pumped through the stationary phase. Dispersion of the mobile phase into the stationary phase occurs, and solutes with lower partition coefficients move faster through the column than those with higher partition coefficients. Depending on the partition coefficients of the solutes, solute separation or extraction can be achieved. If the partition coefficient of a solute is very high, the solute will take a long time to elute from the column. This situation is unfavourable for chromatographic separation, but highly advantageous for extracting astaxanthin from an aqueous algal broth into ethyl acetate. Liquid-liquid chromatographic units exist in hydrodynamic and hydrostatic versions (Ito 2005). In this work, a hydrostatic CPE unit was used. A CPE column is composed of alternately stacked annular plates and annular discs. Chambers are milled into the annular discs, and channels link these chambers. Between two annular discs, an annular plate connects the last chamber of an annular disc with the next through a hole in the annular plate. Annular discs and annular plates are alternately placed on top of each other and mounted on the axis of a centrifuge. A centrifugal force is generated by rotation, and one phase is retained in the chambers (stationary phase, ethyl acetate), while the second phase (mobile phase, algal broth) is pumped through the column from chamber to chamber (Goll et al. 2015). If the mobile phase is the denser phase, this mode is called descending mode; if the mobile phase is the less dense phase, it is called ascending mode. CPE was already used for the 
extraction of $\beta$-carotene from the microalgae Dunaliella salina (Marchal et al. 2013) and torularhodin from the yeast Rhodotorula rubra (Ungureanu et al. 2013).

In this work, an operating parameter selection of the CPE extraction from mechanically disrupted cysts cells and germinated zoospores was made. A techno-economic study was performed to compare the novel CPE extraction processes from homogenised cyst cells and flagellated zoospores with the industrial supercritical $\mathrm{CO}_{2}$ extraction performed in-house or via an external service provider.

\section{Material and methods}

\section{H. pluvialis cyst cell disruption and germination}

The biomass for the CPE extraction experiment was provided by the project partner Sea \& Sun Technology $\mathrm{GmbH}$, Germany. Either mechanically disrupted cyst cells or germinated zoospores were used for CPE extraction. For germination, cyst cells were harvested, centrifuged at $5500 \mathrm{rpm}$ with a Sigma 3-16KL centrifuge from Sigma GmbH (Germany), and washed with distilled water. A previous publication demonstrated that zoospore release was enhanced under heterotrophic germination conditions compared to photo- or mixotrophic germination (Bauer and Minceva 2021). The highest extraction yield of astaxanthin into ethyl acetate was reached by combining mixotrophic and heterotrophic germination conditions at twice the nitrate concentration of the Bolds modified basal medium (BBM), illumination under mixotrophic conditions until nitrate depletion and subsequent germination under heterotrophic conditions (Bauer and Minceva 2021). Thus, to germinate the cyst cells, these were suspended in BBM with $4 \mathrm{mM}$ glucose and illuminated under mixotrophic conditions for $21 \mathrm{~h}$ with a red light (maximum wavelength of $658 \mathrm{~nm}$ ) and at an intensity of $75 \mu \mathrm{mol} \mathrm{m}{ }^{-2} \mathrm{~s}^{-1}$ followed by heterotrophic cultivation for $28 \mathrm{~h}$ (Bauer and Minceva 2021). Red light was chosen, as higher $H$. pluvialis growth rates compared to fluorescence lamps have been reported in the literature (Katsuda et al. 2004). The germination was done at ambient air without additional $\mathrm{CO}_{2}$. CPE extraction was performed $49 \mathrm{~h}$ after the start of germination when the maximum zoospore release was achieved. Mechanical cell wall disruption of $H$. pluvialis cyst cells was performed using the APV 1000 high-pressure homogeniser from APV Systems (Denmark) at 750 bar. Mechanical cell wall disruption was carried out in one or three cycles.

\section{Astaxanthin quantification}

The biomass astaxanthin content of the biomass and extracted into ethyl acetate was determined as described in our previous study (Bauer and Minceva 2019). For HPLC analysis, the astaxanthin extract was dissolved in solvent B (methanol, MTBE, water, 8:89:3, v/v) and filtered with a $0.22 \mu \mathrm{m}$ disposable nylon syringe filter. The astaxanthin quantification was carried out on an HPLC unit (LC-20AB, Shimadzu, Japan), using a YMC carotenoid column $(\mathrm{C} 30,3 \mu \mathrm{m}, 150 \times 4.6 \mathrm{~mm}$, YMC Co., Japan) with a diode array detector (SPD-M20A, Shimadzu, Japan) according to our previous study (Bauer and Minceva 2019). Solvent A (methanol, MTBE, water, $81: 15: 4, \mathrm{v} / \mathrm{v}$ ) and solvent B (methanol, MTBE, water, $8: 89: 3, \mathrm{v} / \mathrm{v}$ ) were used as the mobile phase. The gradient of the solvent A and B was as follows: $2 \%$ solvent B for $11 \mathrm{~min}$, a linear gradient from $2 \%$ solvent B to $40 \%$ solvent B for $7 \mathrm{~min}, 40 \%$ solvent B for 6.5 min followed by a linear gradient to $100 \%$ solvent B for $2.5 \mathrm{~min}, 100 \%$ solvent B for $3 \mathrm{~min}$, a linear gradient to $2 \%$ solvent B for $3 \mathrm{~min}$, held for $3 \mathrm{~min}$. The mobile phase flow rate was

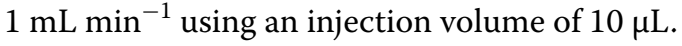

\section{Extraction of astaxanthin from $H$. pluvialis using a centrifugal partition extractor}

Extraction experiments were conducted using the centrifugal partition extractor CPC 250 PRO SPECIAL BIO Version (acronym CPE) from Armen Instrument (France), with an experimentally determined column volume of $244 \mathrm{~mL}$ (Roehrer and Minceva 2019). The column consists of 12 discs, where each disc has 20 engraved twin-cells resulting in a total of 240 cells. The discs are made of stainless steel and are also coated with polytetrafluoroethylene. The maximum rotational speed achievable was $3000 \mathrm{rpm}$, with a permitted pressure drop of 100 bar. Two isocratic pumps, model $30650 \mathrm{C}$, from Gilson (USA), equipped with an 806 Manometric Module (Gilson, USA), were used to pump the two liquid phases for the CPE extraction experiments.

The process for the extraction of astaxanthin from zoospores or mechanically disrupted cyst cells using a CPE unit is presented schematically in Fig. 3. First, the CPE unit was filled with ethyl acetate (saturated with water) as a stationary phase (see Fig. 3a). The rotation was set to $1800 \mathrm{rpm}$, and then water (saturated with ethyl acetate) was pumped (see Fig. 3b). Depending on the set flow rate, a specific amount of the stationary phase was displaced from the column.

When the column reaches its hydrodynamic equilibrium, i.e. no more stationary phase leaves the column, the algal broth (zoospores or mechanically disrupted cyst cells) was injected into the column via a $20-\mathrm{mL}$ injection loop (Fig. 3c). The injected biomass concentrations $c_{D W, \text { injected }}$ of each experiment are presented in Table 1. After injection, water (saturated with ethyl acetate) was continuously pumped, and astaxanthin was extracted from the aqueous algal broth (zoospores or mechanically disrupted cyst cells) into ethyl acetate (see Fig. 3d). After 


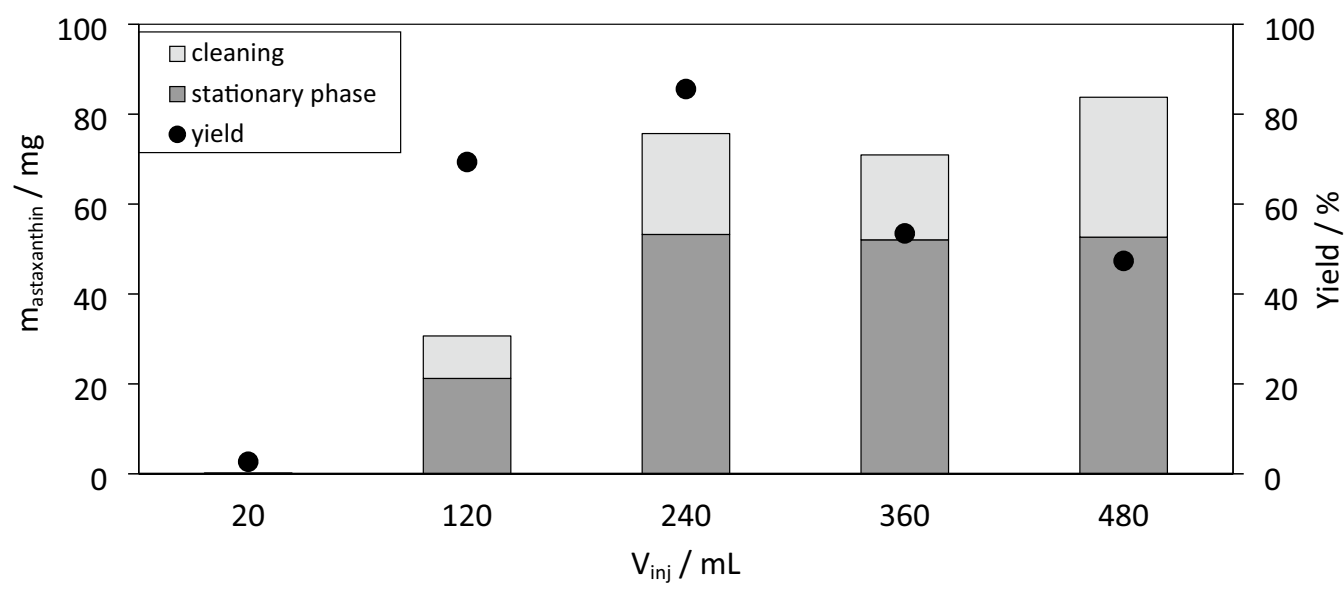

Fig. 3 Astaxanthin extracted into the stationary phase and after cleaning the CPE unit with $80 \mathrm{~mL}$ acetone, for injection volumes of 20, 120, 240, 360 , and $480 \mathrm{~mL}$ of homogenised cyst cells with biomass concentrations of $33 \mathrm{~g} \mathrm{~L}^{-1}$, and a flow rate of $40 \mathrm{~mL} \mathrm{~min}^{-1}$ at a rotational speed of $1800 \mathrm{rpm}$

Table 1 Examined operating conditions of the used CPE column

\begin{tabular}{|c|c|c|c|c|c|c|}
\hline Cell treatment & $\omega / \mathrm{rpm}$ & $\mathrm{F} / \mathrm{mL} \min ^{-1}$ & $c_{\mathrm{DW}, \text { injected }} / \mathrm{g} \mathrm{L}^{-1}$ & $V_{\text {injected }} / \mathrm{mL}$ & $m_{\mathrm{DW}, \text { injected }} / \mathrm{g}$ & $t_{\text {switch }} / \min$ \\
\hline \multirow[t]{4}{*}{ Homogenised } & 1800 & 40 & 72.5 & 20 & 1.45 & 1.9 \\
\hline & & 20 & & & & 2.8 \\
\hline & & 10 & & & & 4.0 \\
\hline & & 40 & 24 & & 0.48 & 1.9 \\
\hline \multirow[t]{5}{*}{ Homogenised } & 1800 & 40 & 33 & 20 & 0.66 & 1.75 \\
\hline & & & & 120 & 3.96 & 4.25 \\
\hline & & & & 240 & 7.85 & 7.25 \\
\hline & & & & 360 & 11.88 & 10.25 \\
\hline & & & & 480 & 15.84 & 13.25 \\
\hline Homogenised & 1800 & 40 & 31.5 & 240 & 7.55 & 7.25 \\
\hline Germinated & & 40 & 23 & 240 & 5.56 & 7.25 \\
\hline
\end{tabular}

a predefined time $t_{\text {switch }}$ (Eq. 1) (Fig. 3d), the solvent-rich phase was pumped into the column (Fig. 3e), causing the displacement of the content from the column. The first fractions collected contained the water-rich phase. After the whole water-rich phase was eluted from the column, the solvent-rich phase-loaded with astaxanthin-was eluted from the column, starting with the least concentrated fraction. The column was cleaned by injecting $80 \mathrm{~mL}$ acetone before the next extraction run was performed. Aliquots of the collected stationary phase and acetone used for cleaning were pipetted into $4 \mathrm{~mL}$ vials, evaporated using an Alpha 3-4 LSC basic freeze dryer from Martin Christ Gefriertrocknungsanlagen $\mathrm{GmbH}$ (Germany) and further processed to analyse the astaxanthin content using HPLC.

The switching time, $t_{\text {switch, }}$ was calculated according to Eq. 1, where $V_{\mathrm{MP}}$ represents the volume of the water-rich phase in the column, $F$ the flow rate of the mobile phase, and $V_{\text {inj }}$ the injection volume of the zoospores or disrupted cyst cells. Equation 1 gives the time theoretically required for the extracted zoospore or disrupted cyst cells to leave the CPE column:

$$
t_{\text {switch }}=\frac{V_{\mathrm{MP}}+V_{\mathrm{inj}}}{F} .
$$

The astaxanthin extraction yield $Y$ was defined according to Eq. 2, as the sum of the extracted mass of astaxanthin in the stationary phase (solvent) $m_{\mathrm{ATX}, \mathrm{SP}}$ and the amount of astaxanthin recovered after cleaning off the CPE column $m_{\mathrm{ATX} \text {,clean}}$, divided by the amount of astaxanthin in the feed biomass injected, i.e. $m_{\mathrm{ATX}, F}$ (see Fig. 3c): 


$$
Y=\frac{m_{\mathrm{ATX}, \mathrm{SP}}+m_{\mathrm{ATX}, \mathrm{clean}}}{m_{\mathrm{ATX}, F}} .
$$

Astaxanthin cannot be extracted from cyst cells into ethyl acetate. Hence, $Y$ depends on the number of released zoospores or mechanically disrupted cyst cells. Therefore, the yield $Y_{\text {extract}}$, which considers the actual extractable amount of astaxanthin from the algal broth, was defined (Eq. 3):

$$
Y_{\text {extract }}=\frac{Y}{Y_{\text {single-stage extraction }}} .
$$

The extractable astaxanthin from the feed (zoospores or mechanically disrupted cyst cells) was determined for each extraction experiment by mixing $5 \mathrm{~mL}$ algal broth with $5 \mathrm{~mL}$ ethyl acetate using a Multi Bio RS-24 shaker from Biosan (Riga, Latvia) for $60 \mathrm{~min}$. The samples were then centrifuged at $5500 \mathrm{rpm}$ for 15 min with a Sigma 3-16KL centrifuge from Sigma GmbH (Germany). The mass of astaxanthin extracted into the solvent divided by the mass of astaxanthin in the feed before extraction defines the yield $Y_{\text {single-stage extraction }}$.

The total extraction time $t_{\text {extraction }}$ was defined as the sum of filling the column with the stationary phase $\left(t_{\text {fill- }}\right.$ ing $)$, equilibration time $\left(t_{\text {equilibration }}\right)$, the time until the column was empty $\left(t_{\text {switch }}\right)$, the time for fractioning the stationary phase $\left(t_{\text {fractioning }}\right)$, and the time for cleaning the column $\left(t_{\text {cleaning }}\right)$ and is presented in Eq. 4 :

$$
\begin{aligned}
t_{\text {extraction }}= & t_{\text {filling }}+t_{\text {equilibration }}+t_{\text {switch }} \\
& +t_{\text {fractioning }}+t_{\text {cleaning }} .
\end{aligned}
$$

The conducted CPE experiments are presented in Table 1. The first set of experiments was performed to evaluate the influence of the biomass concentration and mobile flow rate on the extraction performance.

In the second set of experiments, the injection volume of the algal broth was increased from 20 to $480 \mathrm{~mL}$. In the third set of experiments, extraction from germinated zoospores and homogenised cyst cells was done.

\section{Results and discussion}

The objective of this work was to compare four different downstream processing scenarios for the recovery of astaxanthin from $H$. pluvialis. In addition to the existing process, a new process scheme was proposed, performing solvent extraction of astaxanthin from homogenised cyst cells or germinated zoospores using a CPE unit. First, the CPE extraction experiments were conducted using a column with $244 \mathrm{~mL}$ volume to evaluate the process performance, followed by a theoretical scale-up of the process to an industrial CPE unit with a 5-L column volume. Subsequently, the mass balances of the upstreaming and downstreaming process of four different scenarios (Fig. 2), supercritical extraction both in-house $\mathrm{CO}_{2}$ (D1) and by an external service provider (D4), as well as the extraction of astaxanthin from mechanically disrupted cyst cells (D2) and germinated zoospores (D3) using CPE extraction are discussed. Finally, the total capital investment and total product costs were determined, and an economic analysis was performed.

Extraction of astaxanthin from $H$. pluvialis using a CPE unit First, $20 \mathrm{~mL}$ of homogenised cyst cells with a concentration of $72.5 \mathrm{~g} \mathrm{~L}^{-1}$ were injected at three different flow rates of the mobile phase: 10,20 , and $40 \mathrm{~mL} \mathrm{~m}^{-1}$. Additionally, at a flow rate of $40 \mathrm{~mL} \mathrm{~min}{ }^{-1}$, a further $20 \mathrm{~mL}$ with a biomass concentration of $24 \mathrm{~g} \mathrm{~L}^{-1}$ was injected. The highest extraction yield $Y$ of $72 \%$ was reached at a flow rate of $40 \mathrm{~mL} \mathrm{~min}^{-1}$ and an injected biomass concentration of $24 \mathrm{~g} \mathrm{~L}^{-1}$. In comparison, a yield of $46 \%$ was achieved at a flow rate of $40 \mathrm{~mL} \mathrm{~min}{ }^{-1}$ and an injected biomass concentration of $72.5 \mathrm{~g} \mathrm{~L}^{-1}$. This suggests that a high biomass concentration of $72.5 \mathrm{~g} \mathrm{~L}^{-1}$ compared to $24 \mathrm{~g} \mathrm{~L}^{-1}$ limits the mass transfer of astaxanthin into the solvent due to the increased viscosity at higher biomass concentrations than at lower ones. Extraction yields of $65 \%$ and $58 \%$ were reached at an injected biomass concentration of $72.5 \mathrm{~g} \mathrm{~L}^{-1}$ and flow rates of the mobile phase of $20 \mathrm{~mL} \mathrm{~min}^{-1}$ and $10 \mathrm{~mL} \mathrm{~min}{ }^{-1}$, respectively. Despite the shorter residence time of the biomass in the CPE unit of $1.8 \mathrm{~min}$ at a flow rate of $20 \mathrm{~mL} \mathrm{~min}{ }^{-1}$ compared to $2.0 \mathrm{~min}$ at a flow rate of $10 \mathrm{~mL} \mathrm{~min}^{-1}$, the yield was larger at the higher flow rate. Higher contact area between the cells and the solvent result of a better dispersion of the cells in the solvent-rich stationary phase at a higher flow rate at a higher flow rate. The lower yield at a flow rate of $40 \mathrm{~mL} \mathrm{~min}{ }^{-1}$, compared to 20 or $10 \mathrm{~mL} \mathrm{~min}^{-1}$, could be due to the short residence time of $1.4 \mathrm{~min}$ of the biomass in the CPE unit at a higher flow rate.

The subsequent experiments were performed at a

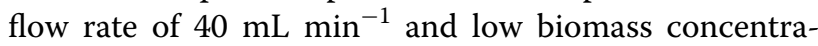
tions of $33 \mathrm{~g} \mathrm{~L}^{-1}$ and an astaxanthin content of $1.13 \mathrm{wt} \%$. The injection volume of the homogenised algal broth was gradually increased from 20 to $480 \mathrm{~mL}$. After each experiment, $80 \mathrm{~mL}$ of acetone was injected into the CPE column to recover any residues adsorbed onto the CPE column. Figure 4 shows the mass of astaxanthin in the fractions of the stationary phase collected and in the cleaning fraction with acetone. The maximum amount of astaxanthin extracted into the stationary phase is approx. $54 \mathrm{mg}$ for injection volumes of $240 \mathrm{~mL}$ to $480 \mathrm{~mL}$. Consequently, the extraction yield calculated using Eq. 2 drops from a maximum of $85 \%$ at an injection volume of $240 \mathrm{~mL}$ to $48 \%$ at $480 \mathrm{~mL}$. This is due to an increasing amount of biomass, leaving the CPE unit non-extracted. 


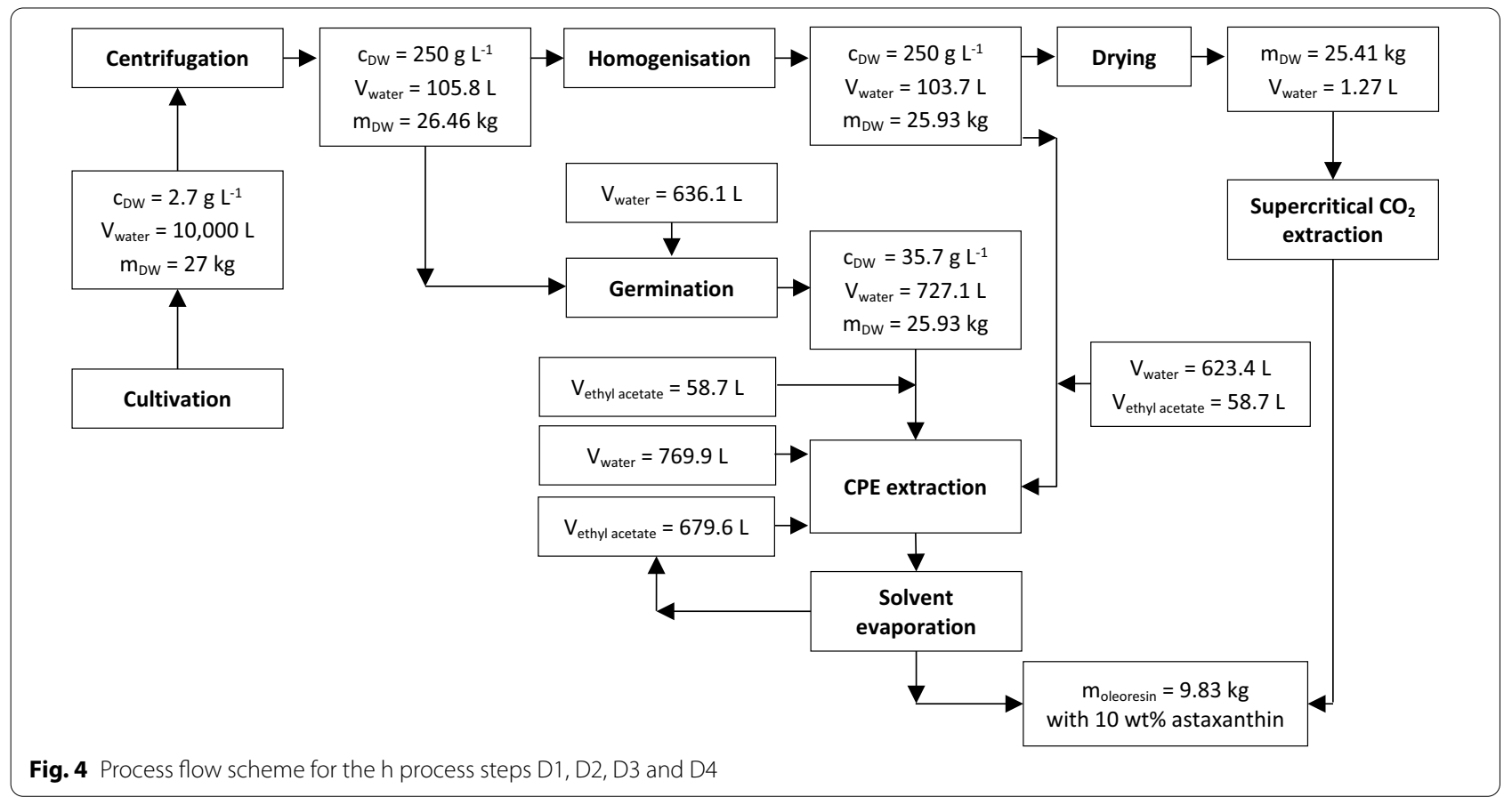

After fractionating the stationary phase, significant amounts of astaxanthin could be recovered by injecting $80 \mathrm{~mL}$ of acetone. The relatively strong absorption of the carotenoid is probably due to the CPE unit being coated with polytetrafluoroethylene. The injection volume of $240 \mathrm{~mL}$ corresponds to an injected biomass of $7.85 \mathrm{~g}$. From the biomass injected, $3.5 \mathrm{~g}$ oleoresin with $2.16 \mathrm{wt} \%$ astaxanthin was recovered in the stationary phase and cleaning step after the solvent had evaporated.

In the last set of experiments, CPE extraction from homogenised cyst cells was compared to that from flagellated zoospores. Therefore, $240 \mathrm{~mL}$ homogenised cyst cells and zoospores with a biomass concentration as reported in Table 1 were injected. Extraction yields of $70 \%$ and $80 \%$ were reached for the extraction from homogenised cyst cells and zoospores, respectively. In the literature, CPE extraction of $\beta$-carotene from living microalgae of Dunaliella salina has already been performed. There, extraction yields of $37 \%$ and $65 \%$ have been reported using decane and ethyl oleate as solvent (Marchal et al. 2013).

\section{Scale-up of the CPE extractor to an industrial scale}

For the scale-up, the results of the experiment with an injection volume of $240 \mathrm{~mL}$ homogenised biomass and a concentration of $33 \mathrm{~g} \mathrm{~L}^{-1}$, an astaxanthin content of $1.13 \mathrm{wt} \%$ in the biomass, and a flow rate of $40 \mathrm{~mL} \mathrm{~min}{ }^{-1}$ was used. An extraction yield of $85 \%$ was reached, and $3.5 \mathrm{~g}$ oleoresin with an astaxanthin content of $2.16 \%$ was extracted from $7.85 \mathrm{~g}$ of biomass with $1.13 \mathrm{wt} \%$ astaxanthin. For the scale-up, it was assumed that the astaxanthin content of the biomass of the cyst cells is $5 \mathrm{wt} \%$, and the astaxanthin content in the oleoresin is at around $10 \mathrm{wt} \%$.

Table 2 shows the processing time for one batch extraction, using the experimental data of the experiment with an injection volume of $240 \mathrm{~mL}$ and a flow rate of $40 \mathrm{~mL} \mathrm{~min}^{-1}$. The CPE experiment conducted was scaled to a commercially available $5 \mathrm{~L}$ CPE from Gilson so that the flow rate resulting in contact time within the column stays the same. As the $5 \mathrm{~L} \mathrm{CPE} \mathrm{unit} \mathrm{consists} \mathrm{of} \mathrm{stainless}$ steel, the column does not need daily cleaning.

Table 3 shows the amount of biomass that can be extracted using one industrial 5-L CPE column in $24 \mathrm{~h}$

Table 2 Process step times in CPE columns with a volume of $244 \mathrm{~mL}$ and $5 \mathrm{~L}$

\begin{tabular}{|c|c|c|c|c|c|c|c|c|c|}
\hline & $V_{\text {column }} / \mathrm{L}$ & $F / m L \min ^{-1}$ & $V_{\text {inj }} / \mathrm{mL}$ & $t_{\text {filling }} / \mathrm{min}$ & $t_{\text {equilibration }} / \min$ & $t_{\text {switch }} / \min$ & $t_{\text {fractioning }} / \mathrm{min}$ & $t_{\text {cleaning }} / \min$ & $t_{\text {extraction }} / \mathrm{min}$ \\
\hline$C P E, V_{\text {inj }}=240 \mathrm{~mL}$ & 0.244 & 40 & 240 & 6.1 & 6.1 & 7.27 & 6.1 & 6.1 & 31.67 \\
\hline Industrial scenario & 5 & 820 & 4918 & 6.1 & 6.1 & 7.27 & 6.1 & 0 & 25.57 \\
\hline
\end{tabular}


and 330 days. Assuming an annual biomass production of $8910 \mathrm{~kg}$ biomass (445.5 $\mathrm{kg}$ astaxanthin), three CPE units with a column volume of $5 \mathrm{~L}$ would be required, which was used for the downstream processes D2 and D3 in the subsequent techno-economic study.

\section{Mass balances of the unit steps of the different downstream scenarios}

The mass flows of each unit operation are presented in Fig. 5. These values were used for calculating the product costs of the process. Subsequently, the assumptions made for the upstreaming process and the unit operations harvesting, cell disruption/germination, spray-drying, CPE extraction, and solvent evaporation are discussed.

\section{Upstream processing}

A two-stage process was assumed for the upstream process, divided into a 10-day growth phase and a 5-day stress phase for astaxanthin accumulation (Fig. 2). The total photobioreactor volume installed was assumed to be $170 \mathrm{~m}^{3}$, as cleaning the harvested reactor $\left(10 \mathrm{~m}^{3}\right)$ each day was considered. It was assumed that $10 \mathrm{~m}^{3}$ of algal broth with a biomass concentration of $2.7 \mathrm{~g} \mathrm{~L}^{-1}$ and an astaxanthin content of $5 \mathrm{wt} \%$ is harvested every day. This means that $8910 \mathrm{~kg}$ of biomass can be harvested annually, which is the typical capacity of a small to medium-sized plant ( $\mathrm{Li}$ et al. 2020). Cultivation on a day-night cycle was assumed so that lighting was required $12 \mathrm{~h}$ per day. The installed power was assumed to be $2 \mathrm{~W} \mathrm{~L}_{\mathrm{algal}}$ broth $^{-1}$. Four rotary vane pumps with a flow of $1200 \mathrm{~L} \mathrm{~h}^{-1}$ each were considered for pumping $10 \mathrm{~m}^{3}$ of algal broth. Based on biomass composition of $\mathrm{CH}_{1.83} \mathrm{O}_{0.48} \mathrm{~N}_{0.11}$ (Panis and Carreon 2016) and a $\mathrm{CO}_{2}$ conversion rate of 0.75 (Acien et al. 2012), $2.66 \mathrm{~kg}$ of $\mathrm{CO}_{2}$ was estimated to produce $1 \mathrm{~kg}$ algal biomass. $\mathrm{CO}_{2}$ was assumed to be dissolved into the algal broth using a $\mathrm{CO}_{2}$ sprinkler. The annual nitrogen consumption was calculated based on the chemical composition of the microalgae mentioned, while further nutrients were determined based on their proportion in the Bolts modified basal medium.

Table 3 Injected amount of biomass, extracted amount of oleoresin and astaxanthin and required number of CPE units in a $24 \mathrm{~h}$ and 330 days operation schedule

\begin{tabular}{|c|c|c|c|c|c|c|c|c|c|}
\hline & \multirow[t]{2}{*}{$t_{\text {extraction }} / \mathrm{min}$} & \multirow{2}{*}{$\begin{array}{l}\text { Injections } \\
\text { in } 24 \mathrm{~h}\end{array}$} & \multicolumn{2}{|c|}{ Biomass injected in } & \multicolumn{2}{|c|}{ Oleoresin extracted in } & \multicolumn{2}{|c|}{ Astaxanthin extracted } & \multirow[t]{2}{*}{ CPE units } \\
\hline & & & $24 \mathrm{~h} / \mathrm{kg}$ & 330 days $/ \mathrm{kg}$ & $24 \mathrm{~h} / \mathrm{kg}$ & 330 days $/ \mathbf{k g}$ & $24 \mathrm{~h} / \mathrm{g}$ & 330 days $/ \mathrm{kg}$ & \\
\hline$C P E, V_{\text {inj }}=240 \mathrm{~mL}$ & 31.67 & 45 & 0.35 & 117 & 0.16 & 52 & 15.8 & 5.2 & 85.7 \\
\hline Industrial scenario & 25.57 & 56 & 9.01 & 2974 & 4.02 & 1325 & 402 & 132.5 & 2.9 \\
\hline
\end{tabular}

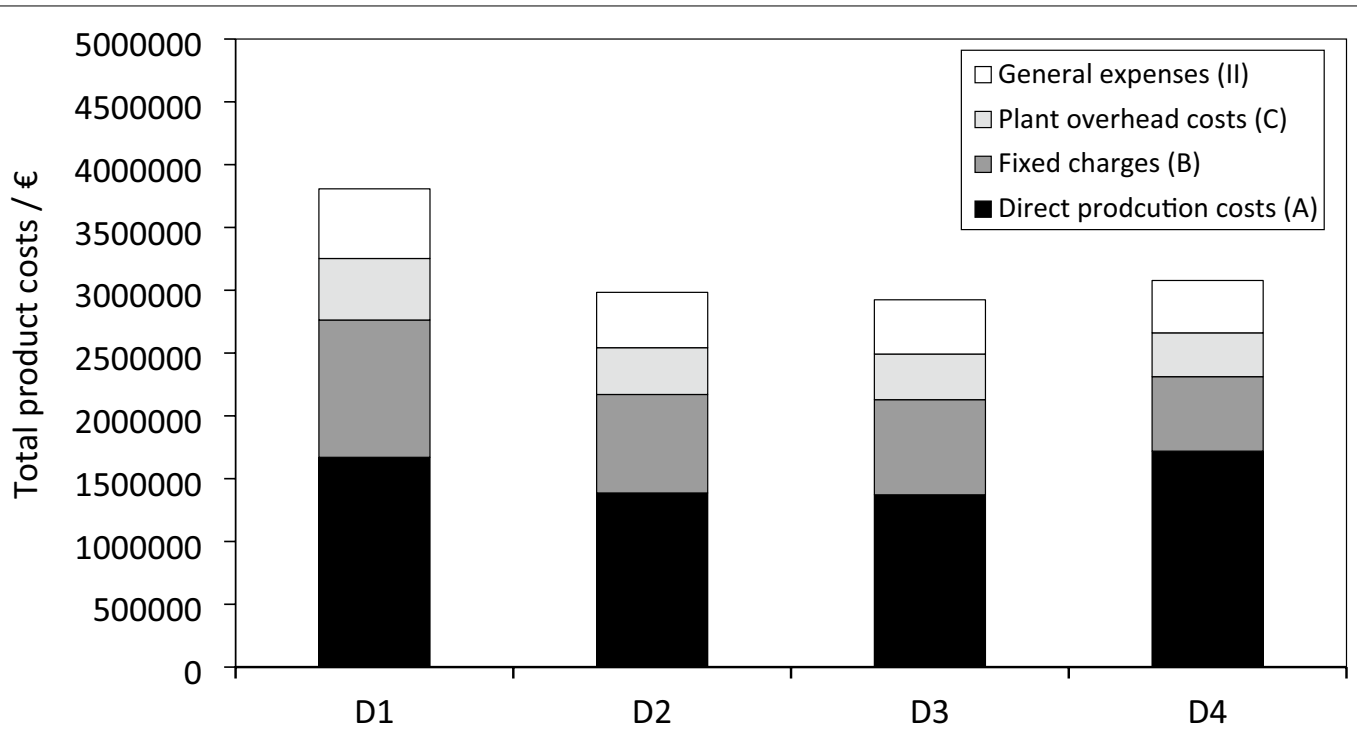

Fig. 5 Composition of the total product costs (III), including the direct production costs (A), fixed charges (B), plant overhead costs (C), and general expenses (II) for the four downstream scenarios D1, D2, D3, and D4 


\section{Harvesting}

A disc-stack centrifuge (GEA SEE 10) was considered as a device for harvesting and concentrating the algal broth from an initial $2.7 \mathrm{~g} \mathrm{~L}^{-1}(0.27 \%$ total suspended solids, TSS) to $250 \mathrm{~g} \mathrm{~L}^{-1}$ (25\% TSS). Accordingly, 9894 L can be separated within $4 \mathrm{~h}$, applying a harvesting flow rate of $2500 \mathrm{~L} \mathrm{~h}^{-1}$. The yield for this process step was assumed to be $98 \%$, corresponding to $29.4 \mathrm{~kg}$ of cyst cells after the centrifugation step.

\section{Cell disruption}

Mechanical disruption using a mechanical high-pressure homogeniser (D1, D2, D4) and germination of the cyst cells (D3) was considered for cyst cell disruption. For the mechanical cyst cell disruption, the high-pressure homogeniser GEA Ariete NS3006H was selected. It was considered to operate at a flow rate of $25 \mathrm{~L} \mathrm{~h}^{-1}$, a pressure of 1500 bar, and an operating time of $4.15 \mathrm{~h}$. For cyst cell germination, the approach described in " $\mathrm{H}$. pluvialis cyst cell disruption and germination" section was scaled to a 1000-L reactor. A combination of mixotrophic or heterotrophic germination of cyst cells was considered, where astaxanthin extraction yields of up to $64 \%$ could be reached $41 \mathrm{~h}$ after the start of germination (Bauer and Minceva 2021). For the scale-up study, two parallel batch photobioreactors with a total volume of $1000 \mathrm{~L}$ (727.1 L cultivation volume with a cell concentration of $35.7 \mathrm{~g} \mathrm{~L}^{-1}$ ) were assumed. Nutrient composition of the BBM with additional $4 \mathrm{mM}$ glucose was considered for germination. As presented in "Extraction of astaxanthin from $H$. pluvialis using a CPE unit" section, an astaxanthin extraction yield of $80 \%$ could be reached for the CPE extraction of germinated zoospores $41 \mathrm{~h}$ after the start of germination. This exceeds the reported astaxanthin extraction yield of $64 \%$ reported and might be due to differences in the cell status of the microalgae (age, nitrate level, etc.). To the author's knowledge, the germination of $H$. pluvialis cyst cells is not established on the industrial scale yet, but germination efficiencies were assumed for this study, which would enable a yield of $85 \%$ in the subsequent CPE extraction.

The yield of the unit steps of mechanical homogenisation and germination was assumed to be $98 \%$, resulting in $25.93 \mathrm{~kg}$ biomass that can be processed in the subsequent unit operations of spray-drying (D1 and D4) or CPE extraction (D2 and D3).

\section{Spray-drying}

Using the GEA production minor spray dryer, drying with an evaporation rate of $16 \mathrm{~L}_{\text {water }} \mathrm{h}^{-1}$ was considered in this study for drying the algal biomass for subsequent extraction with supercritical $\mathrm{CO}_{2}$. The water content of $103.7 \mathrm{~L}$ can be reduced to $1.27 \mathrm{~L}\left(5 \mathrm{wt} \%_{\text {water }}\right.$ in the biomass) within around $6.4 \mathrm{~h}$. In this process step, a yield of $98 \%$ was considered, which corresponds to $25.41 \mathrm{~kg}$ of dry biomass (Panis and Carreon 2016).

\section{Extraction with supercritical $\mathrm{CO}_{2}$}

For in-house supercritical $\mathrm{CO}_{2}$ extraction, using a $2 \times 40 \mathrm{~L}$ (40 L net extractor volume) unit from NATEX Prozesstechnologie GesmbH, with 1000 bar operating pressure, was considered, which can process up to 10 tonnes of biomass within 330 days of annual operation. Applying these pressures, extraction with supercritical $\mathrm{CO}_{2}$ can be performed without an additional co-solvent (Tippelt 2019). An annual loss of 1 tonnes of $\mathrm{CO}_{2}$ must be considered, according to the manufacturer. For supercritical $\mathrm{CO}_{2}$ extraction via an external service provider (D4), it was assumed that the daily produced biomass would be stored at $-20{ }^{\circ} \mathrm{C}$ in a cold storage facility until $1000 \mathrm{~kg}$ are collected for shipment. As $25.41 \mathrm{~kg}$ biomass is collected daily after drying, this corresponds to a 40-day accumulation time.

\section{CPE extraction}

As presented in "Scale-up of the CPE extractor to an industrial scale" section, three CPE units with a column volume of $5 \mathrm{~L}$ are required to process $25.93 \mathrm{~kg}$ homogenised cyst cells or zoospores daily. Per batch injection, $0.161 \mathrm{~kg}$ algal biomass could be processed within $25.57 \mathrm{~min}$ (Table 3). Therefore, 56 batch injections are required daily per $\mathrm{CPE}$ unit, corresponding to a daily process time of $22.9 \mathrm{~h}$. For CPE extraction, the solubility of $7.47 \mathrm{v} / \mathrm{v}$ ethyl acetate in water and $2.96 \mathrm{v} / \mathrm{v}$ water in ethyl acetate must be considered (Stephenson and Stuart 1986). Therefore, the feed must be saturated with ethyl acetate in both scenarios (germinated and homogenised), and the solvent within the CPE column must be saturated with water.

\section{Solvent recovery}

After the extraction of astaxanthin from the algal broth into ethyl acetate using three 5-L CPE units, $637.8 \mathrm{~L}$ of solvent-rich phase, consisting of $618.9 \mathrm{~L}$ ethyl acetate and $18.9 \mathrm{~L}$ water, must be evaporated daily to receive solventfree astaxanthin oleoresin. In addition, separation of ethyl acetate from the water-rich phase was considered, although, according to local authorities in Germany, this is not needed for the quantities discharged into wastewater. At atmospheric pressure, the ethyl acetate content in water can be reduced to $0.01 \mathrm{v} / \mathrm{v}$ in single-stage evaporation and distillate with approx. $89 \mathrm{v} / \mathrm{v}$ ethyl acetate and $11 \mathrm{v} / \mathrm{v}$ water can be obtained (Toth 2019). A high-speed evaporator from Ecodyst, with a capacity of $100 \mathrm{~L}$ and a maximum evaporation rate of $55 \mathrm{~L} \mathrm{~h}^{-1}$, was considered for solvent evaporation. Given an average evaporation 
rate of $50 \mathrm{~L} \mathrm{~h}^{-1}$, total evaporation of $637.8 \mathrm{~L}$ solvent-rich phase takes $12.8 \mathrm{~h}$, and evaporation of the $119.4 \mathrm{~L}$ ethyl acetate from the water-rich phase takes $2.4 \mathrm{~h}$, respectively. Due to the hydrolysis of ethyl acetate to acetic acid and ethanol (Ghobashy et al. 2018), total solvent replacement every 10 days, i.e. 33 times a year, was considered.

\section{Determination of the total capital investment and total product costs}

In the following, the biotechnological production of astaxanthin using the microalgae $\mathrm{H}$. pluvialis, and four different downstream processes, supercritical $\mathrm{CO}_{2}$ extraction performed in-house (D1), solvent extraction from mechanically disrupted cyst cells (D2) and germinated zoospores (D3), and supercritical $\mathrm{CO}_{2}$ extraction performed by an external service provider (D4) are examined about their economic profitability, using the procedure described by Peters and Timmerhaus (1991).

A list of the most important required equipment (TEC) was made for the upstream process and the four downstream scenarios (Turton et al. 2012). This list was used to determine the fixed-capital investments (FCI) and total capital investments (TCI). Finally, the total product costs were calculated as the sum of manufacturing costs and general expenses.

Table 4 lists the most significant equipment costs of the upstream process and the four downstream scenarios. The equipment costs for the upstream process were $€ 965,600$, with the costs of the photobioreactors making up about $50 \%$ of the upstreaming equipment costs. The equipment costs for the downstream processing are presented in Table 4, where the highest equipment costs for the downstream process, at $€ 1.88$ million, were reached for the in-house supercritical $\mathrm{CO}_{2}$ extraction (D1), and the lowest cost was calculated for the external supercritical $\mathrm{CO}_{2}$ extraction (D4) at $€ 0.58$ million. For scenario D4, an additional cooling cell was considered because storage of biomass for around 40 days (up to $1000 \mathrm{~kg}$ ) was assumed before sending it to the external supercritical $\mathrm{CO}_{2}$ extraction service provider. In the conventional downstream processes D1 and D4, the main investment costs are the spray dryer $(€ 450,000)$, and the additional investment costs of around $€ 1.3$ million for the supercritical $\mathrm{CO}_{2}$ extractor must be considered for in-house supercritical $\mathrm{CO}_{2}$ extraction in D1. The list price of a $1 \mathrm{~L} \mathrm{CPE}$ column is around $€ 92,000$. The purchase price of a 5 -L CPC column was estimated from the $1 \mathrm{~L} \mathrm{CPE} \mathrm{col-}$ umn, using the six-tenth-factor rule (Peters and Timmerhaus 1991), resulting in a price of $€ 241,900$ per 5-L CPE column. The total direct plant costs are presented in Table 5 and consider the installation costs, instrumentation and control, piping, buildings, yard improvements, service facilities, and land and are then determined by a share of the TEC (Peters and Timmerhaus 1991; Molina Grima et al. 2003). Furthermore, indirect costs, fixed-capital investment (FCI), and the working capital need to be considered to calculate the

Table 4 Major equipment and total equipment costs (TEC) for the upstream and the four downstream scenarios D1, D2, D3, and D4

\begin{tabular}{|c|c|c|c|c|c|}
\hline List of major equipment & Description & Price/€ & & & \\
\hline Photobioreactors & $170 \mathrm{~m}^{3}$ & & & & 419,900 \\
\hline Light installation & $2 \mathrm{~W} \mathrm{~L}_{\text {algal broth }}{ }^{-1}$ & & & & 480,000 \\
\hline Pumps for cultivation & $68,1200 \mathrm{~L} \mathrm{~h}^{-1}$ each & & & & 27,200 \\
\hline $\mathrm{CO}_{2}$ sparkler & 17 & & & & 8500 \\
\hline Medium preparation tank & $10 \mathrm{~m}^{3}$ & & & & 30,000 \\
\hline \multirow[t]{2}{*}{ Upstreaming } & & & & & 965,600 \\
\hline & & D1 & D2 & D3 & D4 \\
\hline Cooling cell & $A=60 \mathrm{~m}^{2}, \mathrm{k}=0.25 \mathrm{~W} \mathrm{~m}^{-2} \mathrm{~K}^{-1}$ & - & - & - & 7230 \\
\hline Centrifuge & $2.5 \mathrm{~m}^{3} \mathrm{~h}^{-1}$ & 50,000 & 50,000 & 50,000 & 50,000 \\
\hline Homogeniser & $50 \mathrm{Lh}^{-1}, 1500 \mathrm{bar}$ & 75,000 & 75,000 & - & 75,000 \\
\hline Spray dryer & $20 L_{\text {water }} h^{-1}$ & 450,000 & - & - & 450,000 \\
\hline Supercritical $\mathrm{CO}_{2}$ extractor & $2 \times 40 \mathrm{~L}, 1000$ bar & $1,300,000$ & - & - & - \\
\hline Reactor and light for germination & $2 \times 1000 \mathrm{~L}$ & - & - & 6045 & - \\
\hline CPE units & $3 \times 5 \mathrm{~L}$ columns & - & 725,631 & 725,631 & - \\
\hline Pumps for CPC & $1000 \mathrm{~mL} \mathrm{~min}{ }^{-1}$ & - & 105,000 & 105,000 & - \\
\hline Rotary evaporator & $100 \mathrm{~L}$ & - & 116,199 & 116,199 & - \\
\hline Downstream & $€$ & $1,875,000$ & $1,071,830$ & $1,002,875$ & 582,230 \\
\hline Total equipment costs (TEC) & $€$ & $2,840,600$ & $2,037,430$ & $1,968,475$ & $1,540,600$ \\
\hline
\end{tabular}


Table 5 List of the total direct plant costs, the indirect plant costs, the fixed-capital investment and the total capital investment of the four downstream processes D1, D2, D3, and D4

\begin{tabular}{|c|c|c|c|c|c|}
\hline & & D1 & D2 & D3 & D4 \\
\hline Total equipment costs (TEC) & Share of TEC & $2,840,600$ & $2,037,430$ & $1,968,475$ & $1,540,600$ \\
\hline Installation costs & 0.20 & 568,120 & 407,486 & 393,695 & 308,120 \\
\hline Instrumentation and control & 0.13 & 369,278 & 264,866 & 255,902 & 200,278 \\
\hline Piping & 0.20 & 568,120 & 407,486 & 393,695 & 308,120 \\
\hline Electrical & 0.10 & 284,060 & 203,743 & 196,848 & 154,060 \\
\hline Buildings & 0.23 & 653,338 & 468,609 & 452,749 & 354,338 \\
\hline Yard improvements & 0.12 & 340,872 & 244,492 & 236,217 & 184,872 \\
\hline Service facilities & 0.20 & 568,120 & 407,486 & 393,695 & 308,120 \\
\hline Land & 0.05 & 142,030 & 101,872 & 98,424 & 77,030 \\
\hline Total direct plant costs & Share of TEC & $6,334,538$ & $4,543,469$ & $4,389,700$ & $3,435,538$ \\
\hline Engineering supervision & 0.30 & 852,180 & 611,229 & 590,543 & 462,180 \\
\hline Construction expenses & 0.10 & 633,454 & 454,347 & 438,970 & 343,554 \\
\hline Indirect costs & & $1,485,634$ & $1,065,576$ & $1,029,513$ & 805,734 \\
\hline Total direct and indirect plant costs (TDIPC) & Share of TDIPC & $7,820,172$ & $5,609,045$ & $5,419,213$ & $4,241,272$ \\
\hline Contractor's fee & 0.03 & 234,605 & 168,271 & 162,576 & 127,238 \\
\hline Contingency & 0.07 & 547,412 & 392,633 & 379,345 & 296,889 \\
\hline Fixed-capital investment (FCl) & Share of TCl & $8,602,189$ & $6,169,949$ & $5,961,134$ & $4,665,399$ \\
\hline Working capital & 0.11 & $1,063,231$ & 762,606 & 736,796 & 576,643 \\
\hline Total capital investment (TCl) & & $9,665,420$ & $6,932,555$ & $6,697,930$ & $5,242,042$ \\
\hline
\end{tabular}

total capital investment (TCI) (Acien et al. 2012). The course of the TCI correlates directly with the TEC, as it is used to determine the total direct and indirect planned costs (TDIPC), as presented in Table 5 .

Subsequently, the manufacturing costs (I) were determined: these consist of the direct production costs (A), fixed charges (B), and the plant overhead costs (C) (Peters and Timmerhaus 1991). Finally, the sum of the manufacturing costs (I) and general expenses (II) gives the total product costs (III) and are presented in Table 6. The composition of the manufacturing costs, which are the sum of the direct production costs (A), fixed charges (B), and plant overhead costs $(\mathrm{C})$, will be discussed in the following. The direct production costs include the raw material costs, which were in the range of $€ 30,873$ (D4) to $€ 65,253$ (D3) and are presented in Table 7 in further detail. The $\mathrm{CO}_{2}$ price for cultivation was assumed to be $€ 0.39$ per $\mathrm{kg}$ (Molina Grima et al. 2003). In total, nutrient costs of $€ 0.50$ per $\mathrm{kg}$ biomass were calculated, which agrees with reported values of $\$ 0.58$ US per $\mathrm{kg}$ of biomass (Molina Grima et al. 2003). The main water consumption was during the daily harvesting of $10 \mathrm{~m}^{3}$ algal broth with water costs of $€ 3.97 \mathrm{~m}^{3}$ (VEA: Wasserpreise für Industriekunden bleiben 2016 stabil 2021). The main raw material costs for CPE extraction were solvent costs for ethyl acetate and acetone for cleaning. A loss of 12 tonnes of $\mathrm{CO}_{2}$ per year for supercritical $\mathrm{CO}_{2}$ extraction results in costs of $€ 4687$, assuming a price of $€ 0.39$ per $\mathrm{kg} \mathrm{CO}_{2}$
(Zgheib et al. 2018). For germination, the costs of nutrients, water, and glucose were considered.

The operating labour costs in chemical production facilities are usually between 10 and $20 \%$ of the total product cost (III) (Peters and Timmerhaus 1991). In this work, a figure of $15 \%$ was assumed. Based on the operating labour costs, the supervisory labour costs and laboratory charges can be estimated (Table 6). The expenses for maintenance and repairs, patents and royalties were calculated as shown in Table 6. Electricity consumption and costs are presented in more detail in Table 8.

An electricity price of $€ 0.18 \mathrm{kWh}^{-1}$ was assumed for Germany (Industriestrom: Vergleich für Unternehmen 2021)

The total electricity costs for upstreaming are 2506.3 $\mathrm{MWh} \mathrm{a}^{-1}$ (Table 8) to produce 8.9 tonnes of biomass. However, the exact power consumption varies greatly, depending on the type of cultivation, closed vs. open systems, climatic zone and temperature of the cultivation location, additional lighting (Panis and Carreon 2016; Acien et al. 2012). In a model calculation for the annual production of 18.3 tonnes and 6.15 tonnes of wet $H$ pluvialis biomass in Livadeia (Greece) and Amsterdam (Netherlands), the energy consumption of 444.8 $\mathrm{MWh} \mathrm{a}^{-1}$ and $291 \mathrm{MWh} \mathrm{a}^{-1}$ were considered for the upstreaming (Panis and Carreon 2016). In that work, the cultivation was carried out without artificial light. The green phase was conducted in closed photobioreactors, 
Table 6 Direct production costs (A), Fixed charges (B) and plant overhead costs (C), manufacturing costs $(\mathrm{I}, \mathrm{A}+\mathrm{B}+\mathrm{C})$, general expenses (II) and total production costs $(I+I)$ of the biotechnological production of astaxanthin from $H$. pluvialis comparing four different downstream scenarios, D1, D2, D3, and D4

\begin{tabular}{|c|c|c|c|c|c|}
\hline & Share of & D1 & D2 & D3 & D4 \\
\hline 1. Raw materials & & 39,347 & 51,987 & 58,799 & 29,096 \\
\hline 2. Operating labour & Approx. 15 of (III) & 567,188 & 444,763 & 436,035 & 456,408 \\
\hline 3. Supervisory/clerical labour & 0.12 of $(2)$ & 68,063 & 53,372 & 52,324 & 54,769 \\
\hline 4. Electricity & & 503,452 & 475,599 & 474,664 & 462,965 \\
\hline 5. Maintenance and repairs & 0.04 (of FCl) & 344,088 & 246,798 & 238,445 & 186,616 \\
\hline 6. Operating supplies & 0.1 of (5) & 34,409 & 24,680 & 23,845 & 18,662 \\
\hline 7. Laboratory charges & 0.1 of $(2)$ & 56,719 & 44,476 & 43,603 & 45,641 \\
\hline 8. Patents and royalties & Approx. 0.015 of (III) & 56,828 & 44,561 & 43,686 & 45,728 \\
\hline $\begin{array}{l}\text { 9. Supercritical } \mathrm{CO}_{2} \text { extraction via an external } \\
\text { service provider }\end{array}$ & (€50 per kg biomass) & & & & 419,301 \\
\hline A. Direct production costs & Sum of (1 to 9) & $1,670,092$ & $1,386,235$ & $1,371,401$ & $1,719,185$ \\
\hline Lifetime equipment & 10 years & & & & \\
\hline Initial costs for equipment & & $6,897,829$ & $4,947,491$ & $4,780,049$ & $3,741,039$ \\
\hline Salvage value of equipment & & 689,783 & 494,749 & 478,005 & 374,104 \\
\hline Depreciation equipment per year & $10 \%$ & 620,805 & 445,274 & 430,204 & 336,694 \\
\hline Initial costs for buildings & & $1,562,330$ & $1,120,587$ & $1,082,661$ & 847,330 \\
\hline Salvage value of buildings & & 156,233 & 112,059 & 108,266 & 84,733 \\
\hline Depreciation buildings per year & $3 \%$ & 42,183 & 30,256 & 29,232 & 22,878 \\
\hline 10. Depreciation total per year & & 662,988 & 475,530 & 459,436 & 35,9571 \\
\hline 11. Local taxes & 0.01 of $(\mathrm{FCl})$ & 86,022 & 61,699 & 59,611 & 46,654 \\
\hline 12. Insurance & 0.04 of $(\mathrm{FCl})$ & 344,088 & 246,798 & 238,445 & 186,616 \\
\hline B. Fixed charges & Sum of (10 to 12$)$ & $1,093,097$ & 784,028 & 757,493 & 592,841 \\
\hline C. Plant overhead costs & 0.5 of $(2,3,5)$ & 489,669 & 372,466 & 363,402 & 348,897 \\
\hline I. Manufacturing costs $(A+B+C)$ & & $3,252,858$ & $2,542,728$ & $2,492,296$ & $2,660,923$ \\
\hline 14. Administrative costs & 0.2 of $(2)$ & 113,438 & 88,953 & 87,207 & 91,282 \\
\hline 15. Distribution and marketing costs & Approx. 0.05 of (III) & 189,067 & 148,204 & 145,287 & 152,276 \\
\hline 16. Research and development & 0.02 of (IV) & 80,009 & 80,009 & 80,009 & 80,009 \\
\hline 17. Interest & 0.02 of $(\mathrm{FCl})$ & 172,044 & 123,399 & 119,223 & 93,308 \\
\hline II. General expenses & Sum of (14 to 17$)$ & 554,558 & 440,565 & 431,726 & 416,875 \\
\hline III. Total product cost $(I+\|)$ & & $3,807,416$ & $2,983,294$ & $2,924,022$ & $3,077,798$ \\
\hline
\end{tabular}

Table 7 Raw material costs of the biotechnological production of $H$. pluvialis, comparing four different downstream scenarios D1, D2, D3, and D4

\begin{tabular}{|c|c|c|c|c|c|}
\hline 1. Raw materials costs & & D1 & D2 & D3 & D4 \\
\hline Water cultivation & & 13,101 & 13,101 & 13,101 & 13,101 \\
\hline $\mathrm{CO}_{2}$ cultivation & & 9260 & 9260 & 9260 & 9260 \\
\hline Nutrient cultivation & & 6736 & 6736 & 6736 & 6736 \\
\hline $\mathrm{CO}_{2}$ for extraction & & 4687 & - & - & - \\
\hline $\begin{array}{l}\text { Ethyl acetate (replaced } \\
33 \text { times in } 330 \text { days) }\end{array}$ & & - & 17,327 & 17,327 & - \\
\hline Acetone cleaning & & 5564 & 5564 & 5564 & - \\
\hline Water germination & & - & - & 6.04 & - \\
\hline Nutrient germination & & - & - & 6736 & - \\
\hline Glucose & & - & - & 70 & - \\
\hline Total raw material costs & Euro & 39,347 & 51,987 & 58,799 & 29,096 \\
\hline
\end{tabular}

and astaxanthin accumulation was performed in open ponds. In a hypothetical industrial scenario, based on real production data, for the annual production of 17 tonnes of $P$. tricornutum in Germany using artificial light and a total cultivation volume of $315 \mathrm{~m}^{3}$, the electricity consumption of $92,916.8 \mathrm{MWh} \mathrm{a}^{-1}$ was determined for upstreaming (Derwenskus et al. 2020). This study considered the power consumption of $1100 \mathrm{~W}$ for mixing and circulation of the biomass results per rotary vane pump. Due to the lack of real production data, an artificial light installation of $2 \mathrm{~W} \mathrm{~L}_{\text {algal broth }}{ }^{-1}$ and lighting at $12 \mathrm{~h}$ intervals were assumed, resulting in annual electricity consumption of $1188 \mathrm{MWh} \mathrm{a}^{-1}$. For temperature control, values of $6.25-25 \mathrm{kWh} \mathrm{m}^{-3}$ were reported for $H$. pluvialis cultivation in Shenzhen, China (Li et al. 2011). Therefore, $12.5 \mathrm{kWh} \mathrm{m}^{-3}$ was assumed as the energy consumption for temperature control in this study. Power 
Table 8 Annual electricity costs of the biotechnological production of $\mathrm{H}$. pluvialis, comparing four different downstream scenarios, D1, D2, D3, and D4

\begin{tabular}{|c|c|c|c|c|c|}
\hline 4. Electricity costs & & D1 & D2 & D3 & D4 \\
\hline $\begin{array}{l}\text { Electricity price per } \\
\mathrm{kW} \mathrm{h}^{-1}\end{array}$ & $€ 0.18$ & & & & \\
\hline Pumps and mixing & MWh $a^{-1}$ & 592 & 592 & 592 & 592 \\
\hline Light & MWh $a^{-1}$ & 1188 & 1188 & 1188 & 1188 \\
\hline Temperature control & MWh $a^{-1}$ & 660 & 660 & 660 & 660 \\
\hline Control and sensors & MWh $a^{-1}$ & 65.9 & 65.9 & 65.9 & 65.9 \\
\hline Upstream & MWh $a^{-1}$ & 2506.3 & 2506.3 & 2506.3 & 2506.3 \\
\hline $\begin{array}{l}\text { Cooling cell } \\
\left(\mathrm{k}=0.5 \mathrm{~W} \mathrm{~m}^{-2} \mathrm{~K}^{-1}\right) \\
A=60 \mathrm{~m}^{2} \Delta T=40 \mathrm{~K}\end{array}$ & MWh $a^{-1}$ & - & - & - & 4.75 \\
\hline Centrifugation & MWh $a^{-1}$ & 5.28 & 5.28 & 5.28 & 5.28 \\
\hline Homogenisation & MWh $a^{-1}$ & 7.53 & 7.53 & - & 7.53 \\
\hline Spray-drying & MWh $a^{-1}$ & 48.2 & - & - & 48.2 \\
\hline Germination & MWh $a^{-1}$ & - & - & 2.34 & - \\
\hline CPE extraction & MWh $a^{-1}$ & - & 56.6 & 56.6 & - \\
\hline Solvent evaporation & MWh $a^{-1}$ & - & 66.5 & 66.5 & - \\
\hline $\begin{array}{l}\text { Supercritical } \mathrm{CO}_{2} \\
\text { extraction }\end{array}$ & MWh $a^{-1}$ & 229.7 & - & - & - \\
\hline Downstream & MWh $a^{-1}$ & 290.7 & 135.9 & 130.7 & 65.7 \\
\hline Total electricity & MWh $a^{-1}$ & 2797.0 & 2642.2 & 2637.0 & 2572.0 \\
\hline Total electricity costs & Euro & 503,452 & 475,599 & 474,664 & 462,965 \\
\hline
\end{tabular}

consumption for control and sensors was taken from literature and was adjusted to the cultivation volume of $160 \mathrm{~m}^{3}$ in this study (Derwenskus et al. 2020).

In the downstream process of $H$. pluvialis, the highest energy consumption was calculated for in-house supercritical $\mathrm{CO}_{2}$ extraction (D1) with $290.7 \mathrm{MWh} \mathrm{a}^{-1}$, while reduced electricity consumption levels of 135.9 $\mathrm{MWh} \mathrm{a}^{-1}$ and 130.7 MWh a ${ }^{-1}$ were calculated for solvent extraction from homogenised cyst cells (D2) and flagellated zoospores (D3), respectively. The lowest electricity consumption, of $65.7 \mathrm{MWh} \mathrm{a}^{-1}$, was calculated for the process with external supercritical $\mathrm{CO}_{2}$ extraction (D4). The energy consumption for centrifugation was 5.28 MWh a ${ }^{-1}$ in all four scenarios, corresponding to $1.6 \mathrm{kWh} \mathrm{m}_{\text {algal broth }}{ }^{-3}$. The installed power of the disc-stack centrifuge was $4 \mathrm{~kW}$, with a daily operating time of $4 \mathrm{~h}$ and a harvesting volume of $10 \mathrm{~m}^{3}$. Values of 1-1.4 kWh malgal broth ${ }^{-3}$ have been reported for centrifugation in the literature (Panis and Carreon 2016; Milledge 2013). The electricity consumption levels for mechanical cell wall disruption by homogenisation (D1, $\mathrm{D} 2$, and D4) and germination (D3) were $6.97 \mathrm{MWh} \mathrm{a}^{-1}$ and $5.72 \mathrm{MWh} \mathrm{a}^{-1}$, respectively. The costs for homogenisation were determined from the installed power of $5.5 \mathrm{~kW}$ of the used homogeniser and a daily operating time of $3.84 \mathrm{~h}$.
Energy costs of $5.72 \mathrm{MWh} \mathrm{a}^{-1}$ were calculated for germination, using the data from the upstreaming scenario, and these were transferred to $2 \times 1000 \mathrm{~L}$ photobioreactors. Lighting for $21 \mathrm{~h}$ per germination process was assumed (" $\mathrm{H}$. pluvialis cyst cell disruption and germination" section).

The energy costs for spray-drying were calculated to be $48.2 \mathrm{MWh} \mathrm{a}^{-1}$. To determine these costs, the daily amount of water to be evaporated $(102.45 \mathrm{~kg})$ was multiplied by the evaporation enthalpy of water $\left(\Delta h_{\text {evaporation }}=2442.3 \mathrm{~kJ} \mathrm{~kg}^{-1}\right.$ at $25{ }^{\circ} \mathrm{C}$ (Lide 2005)) and a factor of 2.1. This factor was suggested by the manufacturer and is in good agreement with efficiencies of $40 \%$ and $55 \%$ reported in the literature for spray dryers without and with heat recovery, respectively (Kemp 2012) This corresponds to the energy consumption of $5.13 \mathrm{MJ} \mathrm{kg}_{\text {water }}{ }^{-1}$ and fits well to the values of $5 \mathrm{MJ} \mathrm{kg}$ water $^{-1}$ reported in the literature for this unit operation (Thomassen et al. 2016). For the electricity costs for the CPE extraction (scenario D2 and D3), $2.5 \mathrm{~kW}$ needs to be considered according to the manufacturer Gilson (USA). The daily process time per CPE system was $22.9 \mathrm{~h}$ ("H. pluvialis cyst cell disruption and germination" section).

The selected evaporator for solvent evaporation has an installed power of $13.3 \mathrm{~kW}$, resulting in annual energy consumption of $66.5 \mathrm{MWh} \mathrm{a}^{-1}$, when a daily operating time of $15.2 \mathrm{~h}$ is considered ("Solvent recovery" section). The power consumption of $29 \mathrm{~kW} \mathrm{~h}^{-1}$ for the extraction with supercritical $\mathrm{CO}_{2}$ was provided by the manufacturer, resulting in annual energy consumption of around 229.7 $\mathrm{MWh} \mathrm{a}^{-1}$.

Concerning electricity costs, it could be shown that the extraction of astaxanthin from $H$. pluvialis using CPE extraction (D2 and D3) saves electricity costs compared to in-house extraction with supercritical $\mathrm{CO}_{2}$ (D1) since energy-intensive unit operations such as spraydrying and supercritical $\mathrm{CO}_{2}$ extraction can be replaced. Slightly lower electricity consumption for germination (2.34 $\left.\mathrm{MWh} \mathrm{a}^{-1}\right)$ can be expected compared to highpressure homogenisation $\left(7.53 \mathrm{MWh} \mathrm{a}{ }^{-1}\right)$. In scenario D4, where supercritical $\mathrm{CO}_{2}$ extraction via an external service provider is done, the operation of a cooling cell $\left(T=-20{ }^{\circ} \mathrm{C}\right)$ was considered for storage of the harvested biomass up to $1000 \mathrm{~kg}$ before shipment. Therefore, additional energy consumption of $4.75 \mathrm{MWh} \mathrm{a}^{-1}$ was considered.

The highest direct production costs (A) were found to be $€ 1.72$ million and $€ 1.67$ million for external (D4) and in-house (D1) supercritical $\mathrm{CO}_{2}$ extraction. In comparison, production costs of around $€ 1.4$ million can be expected for the solvent extraction of astaxanthin from homogenised cyst cells (D2) and germinated zoospores 
(D3). For the supercritical $\mathrm{CO}_{2}$ extraction via an external service provider (D4), lower costs for electricity, raw materials, and repairs are outweighed by the payments for the external service provider $\left(€ 419,301, € 50 \mathrm{~kg}_{\mathrm{DW}}{ }^{-1}\right)$. To determine the manufacturing costs (I), in addition to the direct production costs (A), the fixed charges (B) and plant overhead costs (C) need to be determined (Table 6). The fixed charges are the sum of depreciation for equipment and buildings, local taxes, and insurances (Peters and Timmerhaus 1991). A linear depreciation period of 10 years and a residual value of $10 \%$ of the original value were assumed for the equipment costs (Turton et al. 2012). The buildings were depreciated by $3 \%$ annually (Peters and Timmerhaus 1991). Local tax and insurance costs were considered $1 \%$ and $4 \%$ of the FCI, respectively (Table 6) (Peters and Timmerhaus 1991).

Due to the high equipment costs for in-house $\mathrm{CO}_{2}$ extraction (D1), with $€ 663,000$, the resulting annual depreciation on equipment and buildings is higher, compared to solvent extraction from homogenised cyst cells (D2) and zoospores (D3) with $€ 476,000$ and $€ 460,000$, respectively. The lowest depreciation costs of $€ 360,000$ were calculated for an external supercritical $\mathrm{CO}_{2}$ extraction (D4). As the fixed charges (B) are derived from the depreciation, local taxes and insurance costs, at $€ 1.1$ million, these are also highest for in-house supercritical $\mathrm{CO}_{2}$ extraction (D1), followed by $€ 0.78$ and $€ 0.76$ million for solvent extraction from homogenised cyst cells (D2) and zoospores (D3), as well as $€ 0.59$ for supercritical $\mathrm{CO}_{2}$ extraction via an external service provider (D4). The plant overhead costs $(C)$ are $50 \%$ of the costs of the operating labour, supervisory labour and maintenance and repairs (Peters and Timmerhaus 1991) and are presented in Table 6.

The general expenses (II) are the sum of the administrative costs, distribution and marketing, research and development, and interest payments and are shown in Table 6 . An interest rate of $2 \%$ and a $100 \%$ debt financing of the project were assumed. Due to higher investment costs and therefore higher interest payments, the general expenses for in-house supercritical $\mathrm{CO}_{2}$ extraction (D1) are highest at $€ 555,000$, followed by $€ 441,000$ and $€ 432,000$ by solvent extraction from homogenised cyst cells (D2) and flagellated zoospores (D3), as well as $€ 417,000$ by external $\mathrm{CO}_{2}$ extraction. The total product costs (III) are the sum of the manufacturing costs (I) and general expenses (II), as presented in Table 6 and Fig. 5 .

The highest total product costs (III) were determined to be $€ 3.81$ million for the conventional process, with an in-house supercritical $\mathrm{CO}_{2}$ extraction (D1). Total product costs of $€ 2.98$ million and $€ 2.92$ million were determined for the alternative process using CPE extraction from homogenised cysts (D2) and germinated zoospores
(D3). Total product costs of $€ 3.08$ million were calculated for the process in which supercritical $\mathrm{CO}_{2}$ extraction is carried out by a service provider (D4). A comparison of the total product costs for scenarios D2 and D3 with D4 shows that the higher direct production costs in D4 (mainly due to the payment of the external service provider for supercritical $\mathrm{CO}_{2}$ extraction) are offset by lower costs of the fixed charges (mainly due to lower deprecation for equipment and buildings).

\section{Economic performance of the four examined downstream scenarios}

After determining the TCI and the total product costs (III) in the subsequent "Determination of the total capital investment and total product costs" section, the economic performance of the four downstream scenarios will be discussed.

The return on investment (ROI) and the net present value (NPV) were used as key figures for economic profitability:

$$
\mathrm{ROI}=\frac{\mathrm{EAT}}{\mathrm{TCI}} .
$$

As presented in Eq. 5, the ROI is the quotient of the profit after depreciation, interest, and taxes (EAT) and the TCI (Peters and Timmerhaus 1991).

The discount factor $d_{n}$ (Eq. 6) is the factor by which the future cash flow must be multiplied to obtain the present value of the cash flow after $n$ years if invested at interest $i$ (Peters and Timmerhaus 1991):

$$
d_{n}=\frac{1}{(1+i)^{n}} .
$$

The discount factor was defined for yearly payments and annual compounding:

$$
\mathrm{NPV}=\sum_{n=1}^{t} \frac{\mathrm{NB}_{n}}{(1+d)^{n}} .
$$

The NPV of the processes compares the difference between the present value of annual cash flows and the initial required investment (Peters and Timmerhaus 1991). The NPV is calculated according to Eq. 7, where net benefits NB corresponds to the net cash flow at year $n$. The internal rate of return (IRR) was calculated and corresponded to a discount factor at NPV $=0$ and gives the interest rate $i$ at which the initial investment breaks even with the generated cash flows.

A total of $3241 \mathrm{~kg}$ of oleoresin (10 wt\% astaxanthin) could be produced in the four downstream scenarios, as shown in Table 9. A sales price of $€ 1200$ per $\mathrm{kg}$ of oleoresin was assumed, which results in gross revenues of around $€ 3.89$ million. The difference between gross 
Table 9 Economic key figures for the evaluation of the four downstream scenarios, D1, D2, D3, and D4

\begin{tabular}{|c|c|c|c|c|c|}
\hline & & D1 & D2 & D3 & D4 \\
\hline Price of oleoresin ( $\left.10 \mathrm{wt} \%_{\text {astaxanthin }}\right)$ per kg & $€$ & 1200 & & & \\
\hline Oleoresin $\left(10 \mathrm{wt} \%_{\text {astaxanthin }}\right)$ produced per year & $\mathrm{kg}$ & 3241 & & & \\
\hline Gross revenue & $€$ & $3,889,620$ & $3,889,620$ & $3,889,620$ & $3,889,620$ \\
\hline Total product cost & $€$ & $3,805,199$ & $2,981,077$ & $2,921,805$ & $3,075,581$ \\
\hline Interest & $€$ & 172,044 & 123,399 & 119,223 & 93,308 \\
\hline Depreciation & $€$ & 662,988 & 475,530 & 459,436 & 359,571 \\
\hline EBITDA & $€$ & 919,453 & $1,507,472$ & $1,546,474$ & $1,266,918$ \\
\hline EBIT & $€$ & 256,465 & $1,031,942$ & $1,087,038$ & 907,347 \\
\hline EBT & $€$ & 84,421 & 908,543 & 967,815 & 814,039 \\
\hline Profit tax (29\%) & $€$ & 24,482 & 263,478 & 280,666 & 236,071 \\
\hline EAT & $€$ & 59,939 & 645,066 & 687,149 & 577,968 \\
\hline $\mathrm{ROI}$ & $\%$ & 0.62 & 9.30 & 10.26 & 11.03 \\
\hline Operating cash flow & $€$ & 722,927 & $1,120,596$ & $1,146,585$ & 937,539 \\
\hline
\end{tabular}

revenues and total product cost (III), excluding depreciation and interest payments, is the earnings before interest, taxes, depreciation, and amortisation (EBITDA). The EBITDA is an important economic parameter, as it enables the comparison of the economic performance of different companies regardless of interest payments, type of depreciation, and country-specific taxation. Due to the lowest total production costs, the two alternative downstream processes, using CPE extraction (D2 and D3), showed the highest EBITDA with $€ 1.54$ and $€ 1.51$ million, respectively. Consequently, a lower EBITDA was reached for the in-house (D1) and external (D2) supercritical $\mathrm{CO}_{2}$ extraction from homogenised cyst cells (Table 9).

Due to higher depreciation, interest payments, and paid taxes for processes D2 and D3 compared to D4, the profits after depreciation, interest payments, and taxes (EAT) converge and amount to $€ 0.69$ million for process D3, $€ 0.65$ million for D2 and $€ 0.58$ million for D4. The lowest EAT of $€ 0.06$ million was in process D4, due to the highest depreciation and interest payments.

However, the profit itself is not a sufficient parameter for the economic comparison of the processes, as it neglects the TCI to reach the profit (Turton et al. 2012; Peters and Timmerhaus 1991). Therefore, the ROI was calculated as defined in Eq. 5 (Panis and Carreon 2016; Zgheib et al. 2018). The highest ROI of $11 \%$ was reached for the downstream process, performing supercritical $\mathrm{CO}_{2}$ extraction via a service provider (D4), followed by $10.3 \%$ by the solvent extraction from zoospores (D3) and $9.3 \%$ from homogenised cyst cells (D2). Due to low EAT and high TCI, with $0.6 \%$, the ROI is lowest for in-house supercritical $\mathrm{CO}_{2}$ extraction (D4). However, from costs higher than $65 €$ per $\mathrm{kg}$ biomass for supercritical $\mathrm{CO}_{2}$ extraction via an external service provider
(D4), the alternative processes of solvent extraction (D2 and D3) would achieve higher ROI than the contracted supercritical $\mathrm{CO}_{2}$ extraction. For long-term investments, the need for a NPV adjustment, taking the time value of money into account, is required. As presented in Table 10, the highest NPV was determined for scenario D3 with a value of $€ 2.66$ million after an operating time of 10 years. A negative NPV of $€ 3.7$ million is reached for the in-house supercritical $\mathrm{CO}_{2}$ extraction (D1). The IRR is the discount factor for which the NPV of the project is equal to zero and is the interest rate at which the project can just break even. Typically, rates for IRR are $10 \%$ for cost improvement of conventional technologies, $15 \%$ for the expansion of conventional technologies, $20 \%$ for product development, and $30 \%$ for speculative ventures (Van Dael et al. 2015). As shown in Table 10, the highest IRR can be expected for the external supercritical $\mathrm{CO}_{2}$ extraction, followed by the new downstream scenarios of solvent extraction from homogenised cyst cells and flagellated zoospores.

Table 10 Total present value for an interest rate of 2\%, NPV after 10 years and IRR of the four downstream D1, D2, D3, and D4

\begin{tabular}{|c|c|c|c|c|c|}
\hline & & D1 & D2 & D3 & D4 \\
\hline $\mathrm{TCl}$ & & $9,665,420$ & $6,932,555$ & $6,697,930$ & $5,242,042$ \\
\hline $\begin{array}{l}\text { Total present value } \\
\text { of discounted cash } \\
\text { flows }\end{array}$ & $€$ & $5,900,698$ & $9,146,567$ & $9,358,698$ & $7,652,416$ \\
\hline NPV & $€$ & $-3,764,721$ & $2,214,012$ & $2,660,767$ & $2,410,374$ \\
\hline IRR & $\%$ & $<0$ & 8.25 & 9.65 & 10.75 \\
\hline
\end{tabular}




\section{Conclusion}

In this study, an alternative downstream process for the extraction of astaxanthin from $H$. pluvialis was developed, replacing the drying of the biomass and supercritical $\mathrm{CO}_{2}$ extraction with $\mathrm{CPE}$ extraction from homogenised cyst cells or germinated zoospores. Using a CPE unit with a column volume of $244 \mathrm{~mL}, 3.5 \mathrm{~g}$ oleoresin could be extracted from $7.58 \mathrm{~g}$ homogenised $H$. pluvialis biomass within $32 \mathrm{~min}$. A scale-up to an industrial 5-L CPE column showed that up to $2,947 \mathrm{~kg}$ of biomass could be processed within 330 days ( $24 \mathrm{~h}$ a day) of operation. For the techno-economic study, annual algal production of $8910 \mathrm{~kg}$ biomass with $5 \%$ astaxanthin was assumed, resulting in daily production of $9.83 \mathrm{~kg}$ oleoresin. Lower direct production costs were determined for the two alternative extraction processes using $\mathrm{CPE}$ compared to supercritical $\mathrm{CO}_{2}$ extraction. Also the total product costs are lower for the two new processes using CPE extraction compared to the supercritical $\mathrm{CO}_{2}$ extraction processes. After 10 years of operation, the NPV is highest for the CPE extraction from germinated zoospores. It must be noted that the results of the economic study will vary, depending on the individual situation of the $H$. pluvialis companies (financing, taxes, labour and electricity costs, depreciation, and interest rate). However, especially for small-size companies, the CPE extraction described represents an interesting alternative, as extraction can be performed in-house regularly, and the storage of biomass for shipment to a service provider for supercritical $\mathrm{CO}_{2}$ is no longer required.

\section{Abbreviations \\ BBM: Bold modified basal medium; CPE: Centrifugal partition extractor; $d_{n}$ : Discount factor; EAT: Earnings after tax; EBT: Earnings before tax; EBIT: Earnings before interest and taxes; EBITDA: Earnings before interest, taxes, depreciation and amortisation; FCl: Fixed-capital investments; H. pluvialis: Haematococcus pluvialis; IRR: Internal rate of return; NB: Net benefits; NPV: Net present value; ROI: Return on investment; TCl: Total capital investments; TDIPC: Total direct and indirect planned costs; TEC: Total equipment costs.}

\section{Acknowledgements}

This work greatly acknowledges the provision of the H. pluvialis cyst cells by Clemens Elle from Sea \& Sun Technology GmbH, Germany.

\section{Authors' contributions}

AB: conceptualisation, methodology, validation, formal analysis, investigation, methodology, data curation, writing-original draft, writing-review and editing MM: conceptualisation, methodology, validation, resources, writingreview and editing, visualisation, supervision, project administration, funding acquisition. All authors read and approved the final manuscript.

\section{Funding}

This research was funded by the FEDERAL MINISTRY OF ECONOMIC AFFAIRS AND ENERGY (BMWi), Grant Number ZF4025031 SB8 and AB was funded from a fellowship granted by FOUNDATION OF GERMAN BUSINESS (sdw).

\section{Availability of data and materials}

The data supporting the conclusions of this article are included in the main manuscript.

\section{Declarations}

Ethics approval and consent participate

Not applicable.

\section{Consent for publication}

All authors have read this article and have approved its submission to Bioresources and Bioprocessing.

\section{Competing interests}

The authors declare that they have no known competing financial interests or personal relationships that could have appeared to influence the work reported in this paper.

Received: 19 September 2021 Accepted: 27 October 2021

Published online: 08 November 2021

\section{References}

Acien FG, Fernandez JM, Magan JJ, Molina E (2012) Production cost of a real microalgae production plant and strategies to reduce it. Biotechnol Adv 30(6):1344-1353. https://doi.org/10.1016/j.biotechadv.2012.02.005

Astaxanthin Market Size, Share \& Trends Analysis Report (2020) https://www. grandviewresearch.com/industry-analysis/global-astaxanthin-market. Accessed 17 Sept 2020

Bauer A, Minceva M (2019) Direct extraction of astaxanthin from the microalgae Haematococcus pluvialis using liquid-liquid chromatography. RSC Adv 9(40):22779-22789. https://doi.org/10.1039/c9ra03263k

Bauer A, Minceva M (2021) Examination of photo-, mixo-, and heterotrophic cultivation conditions on haematococcus pluvialis cyst cell germination. Appl Sci 11(16):7201. https://doi.org/10.3390/app11167201

Chekanov K, Schastnaya E, Solovchenko A, Lobakova E (2017) Effects of $\mathrm{CO}_{2}$ enrichment on primary photochemistry, growth and astaxanthin accumulation in the chlorophyte Haematococcus pluvialis. J Photochem Photobiol B 171:58-66. https://doi.org/10.1016/j.jphotobiol.2017.04.028

Derwenskus F, Weickert S, Lewandowski I, Schmid-Staiger U, Hirth T (2020) Economic evaluation of up- and downstream scenarios for the coproduction of fucoxanthin and eicosapentaenoic acid with P. tricornutum using flat-panel airlift photobioreactors with artificial light. Algal Res 51:102078. https://doi.org/10.1016/j.algal.2020.102078

Ghobashy M, Gadallah M, El-Idreesy TT, Sadek MA, Elazab HA (2018) Kinetic study of hydrolysis of ethyl acetate using caustic soda. Int J Eng Technol 7(4):1995-1999. https://doi.org/10.14419/ijet.v7i4.14083

Goll J, Audo G, Minceva M (2015) Comparison of twin-cell centrifugal partition chromatographic columns with different cell volume. J Chromatogr A 1406:129-135. https://doi.org/10.1016/j.chroma.2015.05.077

Grünewald K, Hagen C, Braune W (1997) Secondary carotenoid accumulation in flagellates of the green alga Haematococcus lacustris. Eur J Phycol 32(4):387-392. https://doi.org/10.1080/09670269710001737329

Haematococcus Pluvialis Market (2021) https://www.meticulousresearch.com/ product/haematococcus-pluvialis-market-5142. Accessed 25 Mar 2021

Hagen C, Siegmund S, Braune W (2002) Ultrastructural and chemical changes in the cell wall of Haematococcus pluvialis (Volvocales, Chlorophyta) during aplanospore formation. Eur J Phycol 37(2):217-226. https://doi.org/ 10.1017/S0967026202003669

Hatti-Kaul R (2000) Aqueous two-phase systems. Humana Press, Industriestrom: Vergleich für Unternehmen; 2021. https://www.eon.de/de/gk/ strom/industriestromrechner.html?adobe_mc_sdid=SDID\%3D6C0 D58C71AB0F351-46A932B6BA0F57E1\%7CMCORGID\%3D17923CDE 5783D4787F000101\%40AdobeOrg\%7CTS\%3D1619600881\&adobe mc ref=https\%3A\%2F\%2Fwww.google.com\%2F\&utm_term=industries trom\&mc $=0512222000 \& g c l i d=C j w K C A j w j 6 S E B h A O E$ EiwAvFRuKD1BD_ x7p8JWQK7FiwQujLgwOXLM_riCU2UVCACoaGrf9EesV1bA5hoCwlY QAvD_BwE\&gclsrc=aw.ds. Accessed 21 May 2021

Ito $Y$ (2005) Golden rules and pitfalls in selecting optimum conditions for highspeed counter-current chromatography. J Chromatogr A 1065(2):145168. https://doi.org/10.1016/j.chroma.2004.12.044 
Katsuda T, Lababpour A, Shimahara K, Katoh S (2004) Astaxanthin production by Haematococcus pluvialis under illumination with LEDs. Enzyme Microb Technol 35(1):81-86. https://doi.org/10.1016/j.enzmictec.2004.03.016

Kemp IC (2012) Fundamentals of energy analysis of dryers. In: Tsotsas E, Mujumdar A (eds) Modern drying technology, vol 4. Wiley, Hoboken, pp 1-45. https://doi.org/10.1002/9783527631681

Khoo KS, Chew KW, Ooi CW, Ong HC, Ling TC, Show PL (2019a) Extraction of natural astaxanthin from Haematococcus pluvialis using liquid biphasic flotation system. Bioresour Technol 290:121794. https://doi.org/10.1016/j. biortech.2019.121794

Khoo KS, Lee SY, Ooi CW, Fu X, Miao X, Ling TC, Show PL (2019b) Recent advances in biorefinery of astaxanthin from Haematococcus pluvialis. Bioresour Technol 288:121606. https://doi.org/10.1016/j.biortech.2019.121606

Khoo KS, Chew KW, Yew GY, Manickam S, Ooi CW, Show PL (2020) Integrated ultrasound-assisted liquid biphasic flotation for efficient extraction of astaxanthin from Haematococcus pluvialis. Ultrason Sonochem 67:105052. https://doi.org/10.1016/j.ultsonch.2020.105052

Khoo KS, Ooi CW, Chew KW, Foo SC, Lim JW, Tao Y, Jiang N, Ho S-H, Show PL (2021) Permeabilization of Haematococcus pluvialis and solid-liquid extraction of astaxanthin by $\mathrm{CO}_{2}$-based alkyl carbamate ionic liquids. Chem Eng J. https://doi.org/10.1016/j.cej.2021.128510

Krichnavaruk S, Shotipruk A, Goto M, Pavasant P (2008) Supercritical carbon dioxide extraction of astaxanthin from Haematococcus pluvialis with vegetable oils as co-solvent. Bioresour Technol 99(13):5556-5560. https://doi.org/10. 1016/j.biortech.2007.10.049

Li J, Zhu D, Niu J, Shen S, Wang G (2011) An economic assessment of astaxanthin production by large scale cultivation of Haematococcus pluvialis. Biotechnol Adv 29(6):568-574. https://doi.org/10.1016/j.biotechadv.2011.04.001

Li X, Wang X, Duan C, Yi S, Gao Z, Xiao C, Agathos SN, Wang G, Li J (2020) Biotechnological production of astaxanthin from the microalga Haematococcus pluvialis. Biotechnol Adv 43:107602. https://doi.org/10.1016/j.biotechadv. 2020.107602

Lide DR (2005) CRC handbook of chemistry and physics, internet version 2005. CRC Press, Boca Raton

Liu Z-W, Yue Z, Zeng X-A, Cheng J-H, Aadil RM (2019) lonic liquid as an effective solvent for cell wall deconstructing through astaxanthin extraction from Haematococcus pluvialis. Int J Food Sci Technol 54(2):583-590. https://doi. org/10.1111/ijfs.14030

Marchal L, Mojaat-Guemir M, Foucault A, Pruvost J (2013) Centrifugal partition extraction of beta-carotene from Dunaliella salina for efficient and biocompatible recovery of metabolites. Bioresour Technol 134:396-400. https://doi. org/10.1016/j.biortech.2013.02.019

Mendes-Pinto MM, Raposo MFJ, Bowen J, Young AJ, Morais R (2001) Evaluation of different cell disruption processes on encysted cells of Haematococcus pluvialis: effects on astaxanthin recovery and implications for bio-availability. J Appl Phycol 13:9-24

Milledge JJ (2013) Energy balance and techno-economic assessment of algal biofuel production systems. University of Southampton, Southampton

Minceva M, Bauer A (2020) Method of extracting a pigment from microalgae

Molina Grima E, Belarbi EH, Acien Fernandez FG, Robles Medina A, Chisti Y (2003) Recovery of microalgal biomass and metabolites: process options and economics. Biotechnol Adv 20(7-8):491-515. https://doi.org/10.1016/ s0734-9750(02)00050-2

Molino A, Mehariya S, lovine A, Larocca V, Di Sanzo G, Martino M, Casella P, Chianese S, Musmarra D (2018) Extraction of astaxanthin and lutein from microalga haematococcus pluvialis in the red phase using $\mathrm{CO}(2)$ supercritical fluid extraction technology with ethanol as co-solvent. Mar Drugs 16(11):432 https://doi.org/10.3390/md16110432

Nahidian B, Ghanati F, Shahbazi M, Soltani N (2018) Effect of nutrients on the growth and physiological features of newly isolated Haematococcus pluvialis TMU1. Bioresour Technol 255:229-237. https://doi.org/10.1016/j.biortech. 2018.01.130

Nguyen KD (2013) Astaxanthin: a comparative case of synthetic vs. natural product. University of Tennessee, Knoxville. https://trace.tennessee.edu/cgi/ viewcontent.cgi?article $=1094 \&$ context $=$ utk_chembiopubs. Accessed 28 May 2021

Panis G, Carreon JR (2016) Commercial astaxanthin production derived by green alga Haematococcus pluvialis: a microalgae process model and a technoeconomic assessment all through production line. Algal Res 18:175-190. https://doi.org/10.1016/j.algal.2016.06.007
Peters MS, Timmerhaus KD (1991) Plantdesign and economics for chemical engineers. McGraw-Hill, Inc., New York

Praveenkumar R, Lee K, Lee J, Oh Y-K (2015) Breaking dormancy: an energyefficient means of recovering astaxanthin from microalgae. Green Chem 17(2):1226-1234. https://doi.org/10.1039/c4gc01413h

Praveenkumar R, Lee J, Vijayan D, Lee SY, Lee K, Sim SJ, Hong ME, Kim Y-E, Oh Y-K (2020) Morphological change and cell disruption of Haematococcus pluvialis cyst during high-pressure homogenization for astaxanthin recovery. Appl Sci 10(2):513. https://doi.org/10.3390/app10020513

Roehrer S, Minceva M (2019) Evaluation of inter-apparatus separation method transferability in countercurrent chromatography and centrifugal partition chromatography. Separations 6(3):36. https://doi.org/10.3390/separation s6030036

Shah MM, Liang Y, Cheng JJ, Daroch M (2016) Astaxanthin-producing green microalga Haematococcus pluvialis: from single cell to high value commercial products. Front Plant Sci 7:531. https://doi.org/10.3389/fpls.2016.00531

Stephenson R, Stuart J (1986) Mutual binary solubilities - water alcohols and water esters. J Chem Eng Data 31(1):56-70. https://doi.org/10.1021/je000 $43 \mathrm{a} 019$

Sun H, Kong Q, Geng Z, Duan L, Yang M, Guan B (2015) Enhancement of cell biomass and cell activity of astaxanthin-rich Haematococcus pluvialis. Bioresour Technol 186:67-73. https://doi.org/10.1016/j.biortech.2015.02.101

Thomassen G, Egiguren Vila U, Van Dael M, Lemmens B, Van Passel S (2016) A techno-economic assessment of an algal-based biorefinery. Clean Technol Environ Policy 18(6):1849-1862. https://doi.org/10.1007/s10098-016-1159-2

Tippelt M (2019) From lab scale to pilot and production scale using scCO2 at 1000 bar with special focus on Haematococcus pluvialis. In: 17th European meeting on supercritical fluids 2019

Toth AJ (2019) Comprehensive evaluation and comparison of advanced separation methods on the separation of ethyl acetate-ethanol-water highly non-ideal mixture. Sep PurifTechnol 224:490-508. https://doi.org/10.1016/j. seppur.2019.05.051

Turton R, Bailie RC, Whiting WB, Shaeiwitz JA, Bhattacharyya D (2012) Analysis, synthesis and design of chemical processes. Pearson Education, London

Ungureanu C, Marchal L, Chirvase AA, Foucault A (2013) Centrifugal partition extraction, a new method for direct metabolites recovery from culture broth: case study of torularhodin recovery from Rhodotorula rubra. Bioresour Technol 132:406-409. https://doi.org/10.1016/j.biortech.2012.11.105

Van Dael M, Kuppens T, Lizin S, Van Passel S (2015) Techno-economic assessment methodology for ultrasonic production of biofuels. Production of biofuels and chemicals with ultrasound. Biofuels and Biorefineries. Springer, Dordrecht, pp 317-345. https://doi.org/10.1007/978-94-017-9624-8_12

VEA: Wasserpreise für Industriekunden bleiben 2016 stabil (2021) https://www. euwid-wasser.de/news/wirtschaft/einzelansicht/Artikel/vea-wasserpreisefuer-industriekunden-bleiben-2016-stabil.html. Accessed 14 Apr 2021

Xi T, Kim DG, Roh SW, Choi J-S, Choi Y-E (2016a) Enhancement of astaxanthin production using Haematococcus pluvialis with novel LED wavelength shift strategy. Appl Microbiol Biotechnol 100(14):6231-6238. https://doi.org/10. 1007/s00253-016-7301-6

Zgheib N, Saade R, Khallouf R, Takache H (2018) Extraction of astaxanthin from microalgae_processdesign and economic feasibility study. In: Paper presented at the international conference on functional materials and chemical engineering (ICFMCE 2017), Dubai

Zhang CH, Liu JG, Zhang LT (2017) Cell cycles and proliferation patterns in Haematococcus pluvialis. Chin J Oceanol Limnol 35(5):1205-1211. https:// doi.org/10.1007/s00343-017-6103-8

Zhao X, Fu L, Liu D, Zhu H, Wang X, Bi Y (2016) Magnetic-field-assisted extraction of astaxanthin from Haematococcus pluvialis. J Food Process Preserv 40(3):463-472. https://doi.org/10.1111/jfpp.12624

Zou TB, Jia Q, Li HW, Wang CX, Wu HF (2013) Response surface methodology for ultrasound-assisted extraction of astaxanthin from Haematococcus pluvialis. Mar Drugs 11(5):1644-1655. https://doi.org/10.3390/md11051644

\section{Publisher's Note}

Springer Nature remains neutral with regard to jurisdictional claims in published maps and institutional affiliations. 